Research paper

\title{
Microvesicles released from Giardia intestinalis disturb host-pathogen response in vitro
}

\author{
Ingrid Evans-Osses ${ }^{\mathrm{a}}$, Andres Mojoli ${ }^{\mathrm{a}}$, Marta Monguió-Tortajada ${ }^{\mathrm{b}}$, Antonio Marcilla ${ }^{\mathrm{c}, \mathrm{d}}$, \\ Veronica Aran $^{\mathrm{e}}$, Maria Amorim ${ }^{\mathrm{h}}$, Jameel Inal ${ }^{\mathrm{f}}$, Francesc E. Borràs ${ }^{\mathrm{b}, \mathrm{g}}$, Marcel I. Ramirez ${ }^{\mathrm{a}, \mathrm{i}, *}$ \\ a Fundacao Oswaldo Cruz-Instituto Oswaldo Cruz, Av. Brasil 4365, Manguinhos, Rio de Janeiro, Brazil \\ b REMAR-IVECAT Group, Health Science Research Institute Germans Trias i Pujol, Can Ruti Campus, Badalona, Spain \\ c Área de Parasitología, Departamento de Farmacia y Tecnología Farmacéutica y Parasitología, Universitat de València, Av. V.A. Estellés, s/n, 46100 \\ Burjassot, Valencia, Spain \\ d Joint Research Unit on Endocrinology, Nutrition and Clinical Dietetics, Health Research Institute-La Fe, Universitat de Valencia, 46026 Valencia, Spain \\ e Brazilian National Cancer Institute, Rio de Janeiro, Brazil \\ ${ }^{\mathrm{f}}$ Cellular and Molecular Immunology Research Centre, School of Human Sciences, London Metropolitan University, London N7 8DB, UK \\ g Nephrology Service, Germans Trias i Pujol University Hospital, Badalona, Spain \\ h Laboratory of Medical Genomics, AC Camargo Cancer Center, São Paulo, SP, Brazil \\ i Dpto de Bioquimica, Universidade Federal de Parana, Curitiba, PR, Brazil
}

\section{A R T I C L E I N F O}

\section{Article history:}

Received 31 October 2016

Received in revised form

23 December 2016

Accepted 11 January 2017

\section{Keywords:}

Microvesicles

Parasite-host cell interactions

Innate immunity

Diarrhoea

Giardia intestinalis

Extracellular vesicles

\begin{abstract}
A B S T R A C T
Giardia intestinalis (G.I), is an anaerobic protozoan and the aetiological agent of giardiasis, a diarrhoea present worldwide and associated with poverty. G.I has a simple life cycle alternating between cyst and trophozoite. Cysts are transmitted orally to the stomach and transform to trophozoites in the intestine by a multifactorial process. Recently, microvesicles (MVs) have been found to be released from a wide range of eukaryotic cells. We have observed a release of MVs during the life cycle of G.I., identifying MVs from active trophozoites and from trophozoites differentiating to the cyst form. The aim of the current work was to investigate the role of MVs from G.I in the pathogenesis of giardiasis. MVs from $\log$ phase were able to increase the attachment of G. intestinalis trophozoites to Caco-2 cells. Moreover, MVs from G. intestinalis could be captured by human immature dendritic cells, resulting in increased activation and allostimulation of human dendritic cells. Lipid rafts participate in the MV biogenesis and in the attachment to Caco-2 cells. Nevertheless, proteomic analysis from two types of MVs has shown slight differences at the protein levels. An understanding of biogenesis and content of MVs derived from trophozoites might have important implications in the pathogenesis of the disease.
\end{abstract}

(c) 2017 Elsevier GmbH. All rights reserved.

\section{Introduction}

Cell-cell communication is mediated by secreted biomolecules, including peptides, proteins, lipids and nucleic acids. These molecules are also present in extracellular vesicles (EVs: mainly exosomes and microvesicles), which are released from different cell types and are able to bind to receptors on target cells, triggering intracellular signalling that modifies the physiological state of the target cells (Ratajczak et al., 2006).

\footnotetext{
* Corresponding author at: Insitituto Oswaldo Cruz -Fiocruz, Av. Brasil 4365, Manguinhos, Rio de Janeiro, Brazil.

E-mail addresses: marcelr@ioc.fiocruz.br, marcel.ivan.ramirez@gmail.com (M.I. Ramirez)
}

EVs are found at elevated levels in cancer and in different acute and chronic inflammatory diseases including sepsis, stroke, atherosclerosis and diabetes mellitus (reviewed in Lower et al., 2014; Aurelian et al., 2014). They are also found in physiological processes such as coagulation (Julich et al., 2014).

Recently, many authors have described the involvement of EVs during the parasite-host interaction. These authors have shown the presence of EVs of different sizes carrying microRNAs, proteins and pro-inflamatory cytokines modulating the host cell (Marcilla et al., 2014; Evans-Osses et al., 2015; Barteneva et al., 2013)

As the leading cause for protozoal diarrhoea worldwide, the intestinal parasite Giardia intestinalis (Syn G. duodenalis, G. lamblia) is an important pathogen of humans and animals causing morbidity and adversely affecting economies. Giardia has a peculiar biology and represents an interesting biological model to under- 
stand evolution, organelle function, and antigenic variation (Adam, 2001).

Giardia intestinalis has two evolutionary stages, the trophozoite, which is located in the gut of animals and humans and which multiplies by binary fission, and the infectious stage, the cyst, released into the environment in faeces.

Giardia belongs to the phylum Diplomonadida, unicellular eukaryotes that have undergone considerable reductive evolution. The lateral gene transfer (LGT) mechanism, an important evolutionary step in prokaryotes, has been shown in Giardia, supporting this parasite to be included in an early branch of eukaryotic evolution (Embley and Hirt, 1998). These findings provide insights into the evolution of biochemical pathways in early eukaryote evolution, and could be important in understanding the minimization, or even loss, of most cellular systems such as mitochondria, peroxisomes, Golgi apparatus, and a classical endo-lysosomal system.

Pathological cysts are ingested via the oral route and symptoms usually occur after an incubation period of 1-2 weeks, although half of Giardia infections are asymptomatic. After emergence from cysts, the flagellated G. lamblia trophozoites colonize mainly the upper small intestine. Trophozoites reside and replicate in the intestinal lumen and at intestinal epithelial cells, but are not able to invade the mucosa. Although still poorly understood, it is clear that the attachment of the parasite to the mucosal surface is the critical point for its persistence in the host. The parasite contains a ventral disk that seems to be important for attachment (Woessner and Dawson, 2012), while the flagella contributes to correct positioning and orientation of the trophozoites before the attachment (House et al., 2011). The parasite actively engages mucosal immunity and the infection progresses with a low or absent inflammation in most cases (Oberhuber and Stolte, 1997). Most likely, mechanical effects, or some other, as yet not described mechanism, produces villus and brush border microvillus atrophy, leading to digestive enzyme deficiencies (Solaymani-Mohammadi and Singer, 2011), and chronic giardiasis can lead to mucosal inflammation with pronounced villus loss (Hanevik et al., 2007); protease activities may be a direct cause of diarrhoeas in giardiasis. Moreover, Jiménez et al. (2004) found that excretory and secretory antigens (E/S Ags) from G. lamblia induced an intestinal pathogenesis, which coincided with mucosal inflammation in BALB/c mice. Oral administration of the E/S Ags not only stimulated production of antibodies with parasiticidal activity, but also resulted in histological alterations within the intestinal tissue that were comparable to those observed in natural and experimental Giardia infections (Jiménez et al., 2014). After colonization the cyst formation represents a key step in the life cycle of the parasite. This process involves cellular and molecular events. Luján et al. (1996) reported that cholesterol starvation induces encystation.

Three encystation- specific cyst wall proteins (CWP1, 2 and 3) are expressed and concentrated in encystation-specific- vesicles (ESVs) that circulate within the parasite before being transported to the cyst wall (Luján et al., 1996; Reiner et al., 1990; Lauwaet et al., 2007; Faso and Hehl, 2011; Benchimol and De Souza, 2011). Synthesis of ESVs starts 4-6 h after encystation is induced and is completed with the cyst formation by approximately $24 \mathrm{~h}$ (Reiner et al., 1990). Interestingly, the protozoan could be able to release other kinds of vesicles that could be speculated to be associated with the attachment to the intestinal cells and pathogenesis. In preliminary work (Deolindo et al., 2013) we have shown that $G$. Intestinalis may release MVs when exposed to different pHs and inducers. Now, We have continued an in depth analysis of MV biogenesis and of the phenotype of the extracellular vesicles released by the parasite.

We have hypothesized in this work that the response of Giardia intestinalis to environmental stress conditions results in the active release of MVs from the plasma membrane that modulate the hostparasite cell interaction.

\section{Materials and methods}

\subsection{Cell culture}

A human colonic adenocarcinoma cell line, Caco- 2 cell clone C2BBe1 [30], was obtained from the American Type Culture Collection (CRL-2102). Caco-2 cells (passages 57-72) were cultured at $37^{\circ} \mathrm{C}, 5 \% \mathrm{CO}_{2}$ in Dulbecco's Modified Eagle's medium (DMEM; Cellgro, Manassas, VA) supplemented with $10 \%$ foetal bovine serum (FBS) (Life Technologies, Grand Island, NY), 100 U/ml penicillin, and $100 \mathrm{mg} / \mathrm{ml}$ streptomycin. Cells were fed every third day and passaged using $0.025 \%$ trypsin with 0.22 mM EDTA when $80-90 \%$ confluent.

\subsection{Parasite culture and in vitro encystation}

Giardia lamblia strain WB clone C6 was obtained from the American Type Culture Collection (\#50803). Parasites were grown in filter sterilized modified TYI-S-33 medium with $10 \%$ adult bovine serum and $0.05 \%$ bovine bile at $37^{\circ} \mathrm{C}$ in microaerophilic conditions and subcultured when confluent. To collect parasites for experiments, the medium was removed from the culture to eliminate unattached or dead parasites. The tube was refilled with cold, sterile medium and trophozoites detached by chilling on ice for $15 \mathrm{~min}$. Parasites were collected by centrifugation $(1500 \times g$ for $5 \mathrm{~min}$ at $4{ }^{\circ} \mathrm{C}$ ) and washed once with the plating medium of $90 \%$ complete DMEM/10\% Giardia medium. Parasites were then counted using a hemocytometer, and diluted to the appropriate number.

Encystation was induced as described previously (McCaffery and Gillin, 1994). Briefly, the pre-encysting cultures were grown to late $\log$ phase for $48 \mathrm{~h}$ in TYI-S-33 medium ( $\mathrm{pH} 7.1$ ) without antibiotics. Encystation was initiated by removing the spent medium and non-adherent cells and re-nourishing the adherent cells with an encystation medium (TYI-S-33 medium adjusted to pH 7.8 and supplemented with $0.25 \mathrm{mg} / \mathrm{ml}$ bovine bile and $5 \mathrm{mM}$ lactic acid).

\subsubsection{Inhibition of lipid rafts}

Trophozoites from G. intestinalis stationary phase were decanted, washed and ressuspended in TYI-S-33 medium without FBS. The parasites were incubated with 2.5, 5.0 and $10 \mu \mathrm{M}$ de M $\beta C D$ for $1 \mathrm{~h}$ at $37 \mathrm{C}$. After this time the parasites were centrifugated at $1000 \times g$ for $10 \mathrm{~min}$ and the pellet ressuspended with fresh TYI-S-33 medium and used in microvesiculation and adhesion essays.

\subsubsection{Adhesion assay}

The assay was carried out with stationary phase cultures of $G$. Intestinalis trophozoites or with $G$. intestinalis trophozoites treated with $\mathrm{M} \beta C \mathrm{CD}(10 \mu \mathrm{m})$. The parasites were decanted by chilling for 10 min in ice-cold PBS, at pH 7.2. Trophozoite suspensions were centrifuged at $1000 \times g$ for $10 \mathrm{~min}$ and resuspended to a concentration of $1 \times 10^{6} / \mathrm{ml}$. Caco cells were seeded on a coverslip in a concentration of $1 \times 10^{5}$ cells/well. Suspensions of tropho zoites were then co-incubated with cultured cells in a 10:1 ratio. Plates were incubated at $37^{\circ} \mathrm{C}$ in $10 \% \mathrm{CO}_{2}$. After incubating for $1-3 \mathrm{~h}$, unattached trophozoites were counted in a haemocytometer and the\% adhered cells determined. The effect of vesicles was tested in the same experiments incubated with different concentrations of purified MVs.

\subsection{Monocyte isolation}

Cells were obtained from leukocyte residues of healthy donors from the Blood and Tissue Bank (Barcelona, Spain). Peripheral blood 
mononuclear cells (PBMCs) were isolated by density gradient centrifugation using Ficoll-Paque (GE Healthcare, Sweden) and T cells (CD3+) were depleted using the RossetteSep Human CD3 Depletion Cocktail (StemCell Technologies, Seattle, USA). PBMCs depleted of T cells were washed twice with washing buffer $(400 \times \mathrm{g}, 5 \mathrm{~min}$, RT) and were counted using PerfectCount Microspheres (Cytognos, Salamanca, Spain).

Monocytes were then obtained by positive magnetic selection using the Easysep Human anti-CD14 Positive Selection Kit (Stemcell Technologies, France) following the manufacturer's instructions. Monocytes were $>95 \%$ CD14+ and viable (as determined by 7-AAD staining).

\subsection{Differentiation to iDCS}

Monocyte-derived dendritic cells (MDDCs) were generated by culturing monocytes with the differentiation cytokines IL4 and GMCSF for 6 days. Subsequently, isolated monocytes were cultured at $1 \times 10^{6}$ cells/ml in complete medium composed of RPMI 1640 (PAA, Pasching, Austria) supplemented with $5 \%(\mathrm{v} / \mathrm{v})$ heat-inactivated human serum $\mathrm{AB}$ (BioWhittaker, Lonza), $2 \mathrm{mM}$ L-glutamine (Sigma Aldrich, USA), $100 \mathrm{U} / \mathrm{ml}$ penicillin (Cepa, Spain) and $100 \mathrm{U} / \mathrm{ml}$ streptomycin (Normon Laboratories, Spain), with recombinant human IL-4 and GM-CSF (Miltenyi Biotech), both at a final concentration of $1000 \mathrm{U} / \mathrm{ml}$. After six days, immature dendritic cells (iDCs) were harvested by collecting all media and incubating adhered cells with accutase (PAA, Pasching, Austria) for $30 \mathrm{~min}$ at $37^{\circ} \mathrm{C}$. iDCs were then washed with PBS $(400 \times g, 5 \mathrm{~min})$, counted and used for indicated experiments.

\subsection{Generation of MVs}

Plasma Membrane Vesicles (MVs) were produced from the $G$. intestinalis trophozoite. Parasites were grown in TYI-S-33 medium with $10 \%$ adult bovine serum and $0.05 \%$ bovine bile at $37^{\circ} \mathrm{C}$ in microaerophilic conditions and subcultured when confluent. To collect parasites for experiments, the medium was removed from the culture to eliminate unattached or dead parasites. The tube was refilled with cold, sterile medium and trophozoites detached by chilling on ice for $15 \mathrm{~min}$. Parasites were collected by centrifugation ( $1500 \mathrm{xg}$ for $5 \mathrm{~min}$ at $4{ }^{\circ} \mathrm{C}$ ) and were then counted using a hemocytometer, and diluted to $1 \times 10^{6} \mathrm{cells} / \mathrm{ml}$. The parasites were incubated in $1 \mathrm{ml}$ serum-free culture medium (Yi-S) and stimulated with $1 \mathrm{mM} \mathrm{CaCl}$ for $1 \mathrm{~h}$ at $37^{\circ} \mathrm{C}$. This way, MV production was stimulated so it prevailed over exosome release, and thus an enriched MVs-containing medium was obtained. After incubation, all medium was collected, centrifuged at $2500 \times g$ for $5 \mathrm{~min}$ and the supernatant was further centrifuged twice at $4000 \times g$ for $30 \mathrm{~min}$. Afterwards, supernatant was ultracentrifuged at $100,000 \times g$ for $1 \mathrm{~h} 30 \mathrm{~min}$ and the pellets, containing concentrated MVs, were collected. MVs were suspended in PBS and were approximately quantified according to their protein content (Bradford assay). Finally, MVs suspensions were dried using speed vacuuming for storage and shipping. Dried MVs were resuspended in PBS and kept at $4{ }^{\circ} \mathrm{C}$ until further use.

\subsection{Flow cytometry}

MVs were quantified by counting in a BD FACScalibur ${ }^{\mathrm{TM}}$ Flow Cytometer (Becton, Dickinson and Company) using dot plots with SSC and FSC in log scale. Quantification of MVs by FACS analysis was further validated by protein quantification with the Bradford assay.

For surface phosphatidylserine detection MVs were ressupendend in $200 \mu \mathrm{l}$ of annexin-binding buffer (ABB - HEPES $10 \mathrm{mM}$, $\mathrm{NaCl} 140 \mathrm{mM}, \mathrm{CaCl}_{2} 2.5 \mathrm{mM}, \mathrm{pH} 7.2$ ) and incubated with $25 \mathrm{ug} / \mathrm{ml}$
AnnexinV-FITC (Sigma-Aldrich) for $30 \mathrm{~min}$ at room temperature. MVs were diluted in $5 \mathrm{ml}$ of $\mathrm{ABB}$ and centrifuged at $100.000 \times \mathrm{g}$ during $90 \mathrm{~min}$. The MV pellet was ressuspended in $500 \mu \mathrm{l}$ of $\mathrm{ABB}$ and data were collected in a flow cytometer (FACSCalibur, BD Biosciences).

\subsection{MV staining}

MVs were stained with the lipophilic dye PKH-67 (Sigma Aldrich, USA) for capture assays. $6 \mu \mathrm{l}$ of $\mathrm{PKH}-67$ was diluted in $1 \mathrm{ml}$ of diluent Cand MVs were also diluted $1 / 40$ in diluent $C$. Both dilutions were mixed together at a volume ratio of $1: 1$, and labelling was continued for $15 \mathrm{~min}$ at room temperature in the dark. The reaction was stopped by adding $2 \mathrm{ml} \mathrm{EV-free} \mathrm{FBS} \mathrm{(}>16 \mathrm{~h}$ at $100,000 \times g$ ), and MVs were then washed in PBS, and ultracentrifuged at $100,000 \times g$ for $1 \mathrm{~h} 10 \mathrm{~min}$ (SW28 rotor, OptimaTM XL-100K Ultracentrifuge, Beckman).

\subsection{NanoSight analysis}

EVs were resuspended in $100 \mu \mathrm{l}$ of PBS, $50 \mu \mathrm{l}$ of which was diluted 1:10 with $450 \mu \mathrm{l}$ of PBS, and analysed using NanoSight LM10 equipment and NTA software version 2.3 (NanoSight Ltd., Malvern, UK). Images were recorded for $60 \mathrm{~s}$ ( 5 technical replicates) with the folllowing parameters: camera shutter - 1492, camera gain - 512, detection threshold - 10 .

\subsection{MVs capture assay}

To assess the ability of iDCs to capture MVs, $10^{5}$ iDCs were incubated at $37^{\circ} \mathrm{C}$ in $5 \% \mathrm{CO}_{2}$ with PKH-67 labelled MVs $(25 \mu \mathrm{g}$ or $12.5 \mu \mathrm{g}$ ) at a final volume of $150 \mu \mathrm{l}$ complete medium. As a control, iDCs were incubated at $4{ }^{\circ} \mathrm{C}$. Several incubation times were assessed in the different experiments.

After incubation, cells were extensively washed in cold PBS. At this point, they were either stained for capture and phenotype analysis by flow cytometry or left in complete medium at $37^{\circ} \mathrm{C}$ for a further $24 \mathrm{~h}$. After culture, cells were assessed for expression of both activation markers and for allostimulation capabilities. For phenotype analysis, the following murine mAbs were used (BD Biosciences) CD83-APC, HLA-DR-APC-H7, CD25-PE and CD25-PECy5. Isotype-matched $\mathrm{mAbs}$ were used as controls. All analysis was performed in a FACS Canto II flow cytometer (BD Biosciences) and analysed using FlowJo software. For inhibition experiments, cells were treated for $30 \mathrm{~min}$ at $37^{\circ} \mathrm{C}$ with cytochalasin D (Calbiochem, Germany) at the indicated concentrations prior to the addition of MVs.

\subsection{Allostimulation assay}

Allostimulation assays were performed by culturing together 1h-MV pulsed, $24 \mathrm{~h}$-resting MDDCs with allogeneic CFSE-labelled T cells. T cells were isolated from healthy donors' PBMCs by negative magnetic selection using the Easysep Human T cell Enrichment Kit (Stemcell Technologies), and stained with CFSE (0.4 $\mu \mathrm{M}$; Invitrogen).

iDCs were co-cultured with T cells at different ratios, from 1:20 (5000 MDDCs: $100,000 \mathrm{~T}$ cells) to $1: 160$ (625 MDDCs: 100,000 T cells). As a positive control, T cells were stimulated with Phorbol 12-Myristate 13-Acetate (PMA, $0.6 \mathrm{ng} / \mathrm{ml}$, Sigma Aldrich) and Ionomycin calcium salt ( $200 \mathrm{ng} / \mathrm{ml}$, Sigma Aldrich).

After 4.5 days of culture, proliferation was assessed by flow cytometry (LSR Fortessa Analyzer, BD). Proliferative T cells were gated by diluted CFSE intensity. 


\subsection{Cytotoxicity (viability) tests}

Cell viability assays were performed according to Woodhead et al. (2000). Cells were inoculated in 96-multiwell plates (Costar, Corning, NY, USA) at a cell density of $1.2 \times 10^{5}$ cells/well. At confluence, cells were incubated with serially diluted DSS for predetermined time periods. DSS was dissolved in culture media and filter-sterilized using a $0.45 \mu \mathrm{m}$ filter. Viability was assayed by a commercially available kit (Cell Titer $96^{\mathrm{TM}}$ AQueous, Promega, Madison, USA), which depends on the physiologic reduction of MTS to formazan. Analyses were performed in triplicate.

\subsection{Confocal microscopy assays}

To corroborate MV capture and examine the distribution of MVs in pulsed iDCs, $10^{5}$ iDCs were incubated with PKH-67labelled MVs from Giardia intestinalis at $37^{\circ} \mathrm{C}$ for the indicated periods. Then, cells were extensively washed, stained for CD11cPE (ImmunoTools), and fixed with $2 \%$ formaldehyde solution. Fixed cells were mounted in Immunofluorescence slides with ProLong ${ }^{\circledR}$ Gold Antifade Reagent with DAPI (Life Technologies), and were examined in an Axio-Observer Z1 inverted fluorescent Microscope (ZEISS, Germany).

To determine the endocytosis trafficking, MVs-pulsed iDCs were stained for the Early Endosome Antigen (EEA-1; BD Transduction Laboratories) and Transferrin Receptor (TfR; Abcam, UK), followed by Alexa546-anti mouse IgG and anti rabbit IgG, respectively. Labelling was performed with the IntraStain fixative and permeabilization kit (Dako, Denmark). Finally, cells were cytospun onto glass slides and mounted with ProLong ${ }^{\circledR}$ Gold Antifade Reagent with DAPI. Confocal microscopy was performed on an Axio-Observer Z1 microscope with the LSM 70 confocal module (ZEISS, Germany).

\subsection{Proteomic assays}

Samples were digested with sequencing grade trypsin ( $2.5 \mathrm{ng} / \mu \mathrm{L}$; Promega) as described elsewhere (Shevchenko et al., 1996). The digestion mixture was dried in a vacuum centrifuge, resuspended in $50 \mu \mathrm{l}$ of $2 \% \mathrm{ACN}, 0.1 \%$ TFA $1 \mu \mathrm{l}$ of each digested mixture were loaded onto a trap column (NanoLC Column, $3 \mu \mathrm{C} 18 \mathrm{CL}$, $100 \mu \mathrm{m} \times 15 \mathrm{~cm}$; Nikkyo), and desalted with $0.1 \%$ TFA at $2 \mu \mathrm{l} / \mathrm{min}$ during $10 \mathrm{~min}$. The peptides were loaded onto an analytical column (LC Column, $3 \mu \mathrm{C} 18 \mathrm{CL}, 75 \mu \mathrm{m} \times 12 \mathrm{~cm}$, Nikkyo) equilibrated in $5 \%$ acetonitrile $0.1 \%$ FA (formic acid). Peptide elution was carried out with a linear gradient of $5-35 \%$ buffer $B$ in 120 min (A: $0.1 \%$ FA; B: ACN, $0.1 \%$ FA) at a flow rate of $300 \mathrm{nl} / \mathrm{min}$. Peptides were analysed in a mass spectrometer nanoESI qQTOF (5600 TripleTOF, ABSCIEX). The tripleTOF was operated in information dependent acquisition mode, in which a $0.25 \mathrm{~s}$ TOF-MS scan from 350 to $1250 \mathrm{~m} / \mathrm{z}$, was performed, followed by $0.05 \mathrm{~s}$ product ion scans from 100 to $1500 \mathrm{~m} / z$ on the 50 most intense 25 charged ions. The MS/MS information (combined from three runs of one sample) was sent to MASCOT v2.3.02 or to PARAGON via the Protein Pilotv 4.5 (ABSciex).

MASCOT search engine (Matrix Science). Database search was performed on NCBInr Giardia EST. Searches were performed with tryptic specificity allowing one missed cleavage and a tolerance on the mass measurement of $50 \mathrm{ppm}$ in MS mode and 0.6 Da for MS/MS ions. Carbamidomethylation of Cys was used as a fixed modification and oxidation of Met, and deamidation of Asn and Gln as variable modifications.

ProteinPilot v4.5. search engine (ABSciex). ProteinPilot default parameters were used to generate peak list directly from 5600 TripleTof.wiff files. The Paragon algorithm of ProteinPilot was used to search the NCBI protein database with the following parameters: trypsin specificity, cys alkylation, no taxonomy restriction, and the search effort set to through. To avoid using the same spectral evidence in more than one protein, the identified proteins were grouped based on MS/MS spectra by the Protein pilot Progroup algorithm. Thus, proteins sharing MS/MS spectra are grouped, regardless of the peptide sequence assigned. The protein within each group that can explain more spectral data with confidence is shown as the primary protein of the group. Only the proteins of the group for which there is individual evidence (unique peptides with enough confidence) are also listed, usually toward the end of the protein list.

\section{Results}

\subsection{Trophozoites from Giardia intestinalis release extracellular} vesicles (MVs) from the plasma membrane under different environmental conditions

To simulate the dramatic environmental changes during the cell cycle of Giardia intestinalis, we compared the growth curve of trophozoites cultured in vitro for $48 \mathrm{~h}$ under different $\mathrm{pHs}$ ranging

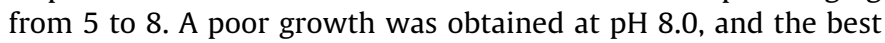
condition was at $\mathrm{pH}$ 7.0. Curiously, the parasite was able to grow at acidic pHs ( $\mathrm{pH} 5.0$ and 6.0), and the growth was highly inhibited at $\mathrm{pH}$ 8.0., a condition in which trophozoites are differentiated to cyst when the parasites are in the presence of inducers such as bile, (Fig. 1A). Due to these growth curve differences, we next analysed whether the trophozoites could release MVs in response to different environmental conditions (Fig. 1B). We saw a high release of MVs at $24 \mathrm{~h}$ at $\mathrm{pH} 7.0$, and no differences were found at different pHs after $48 \mathrm{~h}$ (Fig. 1C).

We also analysed the production of MVs during the first $3 \mathrm{~h}$ in a serum-free medium with added calcium, a well-known microvesicle inducer, and we detected an increase of MV release between 30 to $120 \mathrm{~min}$, maintaining the release up to $180 \mathrm{~min}$ (Fig. 1D). On this basis, we decided to perform an experiment of MV induction for 60 min only.

To characterize the type of MVs released by the trofozoite forms of Giardia intestinalis, we analysed the supernant of trofozoites of cultured in a fetal bovine serum-free medium for $60 \mathrm{~min}$ in the presence of $1 \mathrm{mM}$ of calcium, and subjected to different rounds of centrifugation and final ultracentrifugation. Examination of the preparation by electron microscopy revealed cup-shaped vesicles of $60-150 \mathrm{~nm}$ (Not shown). MVs were also quantified by FACS and analysed for size and granularity and the presence of phosphatidylserine by detecting annexin V-FITC staining (Supplementary Fig. S1). We verified the impact of calcium on MV release using higher concentrations of calcium, as well as EGTA (calcium chelating inhibitor), and a calcium ionophore, an activator of calcium release, as shown in Fig. 1E.

To determine vesicle size variation in the population of extracellular vescicles, we used nanoparticle tracking analysis (Nanosight, Costa Mesa, CA) to directly examine millions of vesicles. This analysis showed a peak with a mean diameter of $201.6 \mathrm{~nm}$ and that more than $50 \%$ were between 150 and $350 \mathrm{~nm}$ in diameter (Fig. 1F)

\subsection{The origin of microvesicles is plasma membrane and lipid raft dependent}

Due to the size of MVs and presence of phosphatidylserine at the surface, we were interested to verify plasma membrane and lipid raft (also named DRMs (detergent-resistant membranes)) involvement in the biogenesis of G. intestinalis MVs. We investigated whether the disruption of lipid rafts from trophozoite plasma membranes affected MV formation, as it was defined previously (Del Conde et al., 2005). To assess this effect, we treated trophozoite 


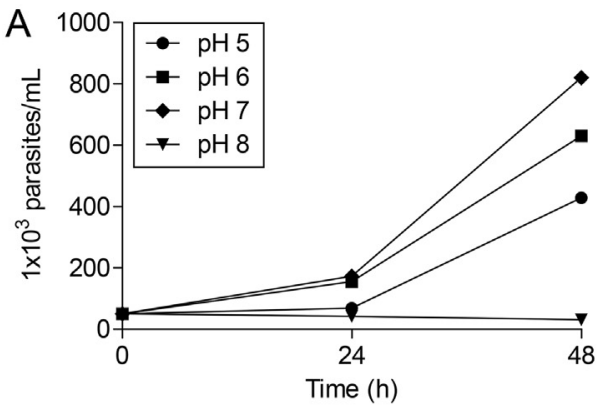

C
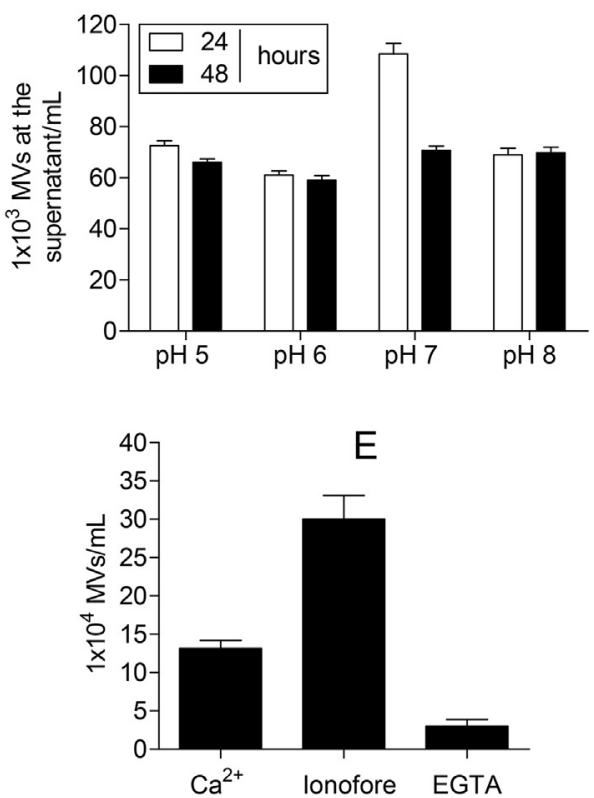

B

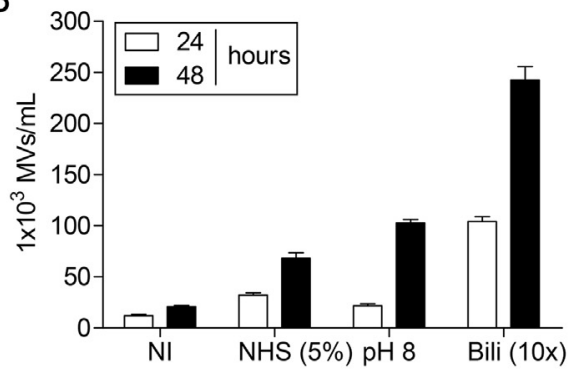

D

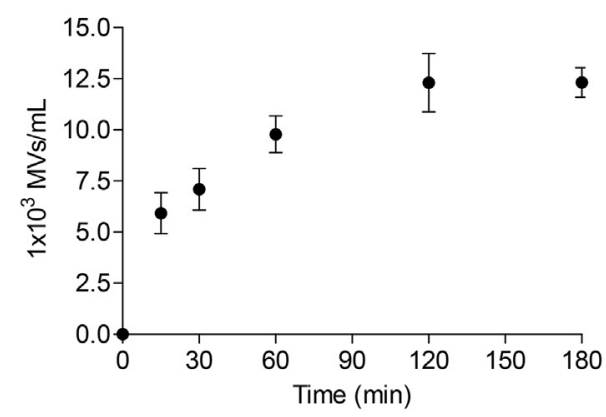

$\mathrm{F}$
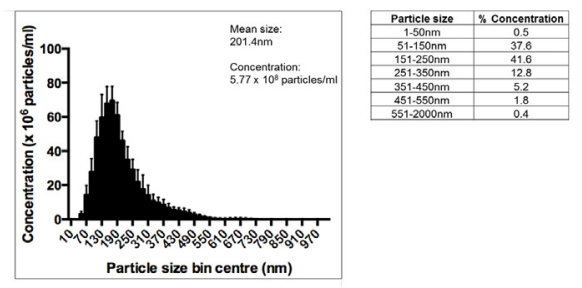

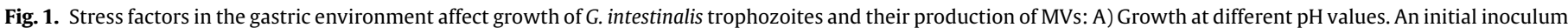

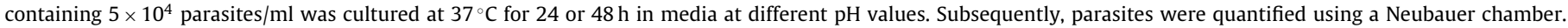

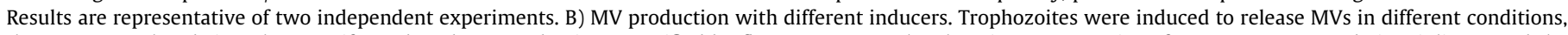

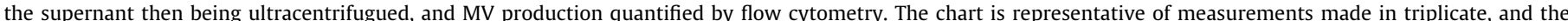

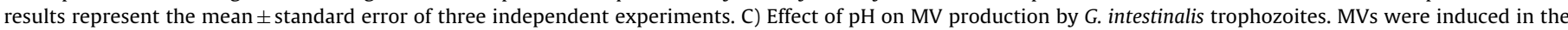

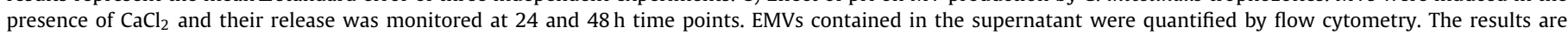

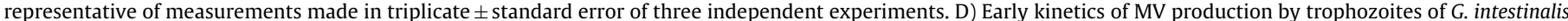

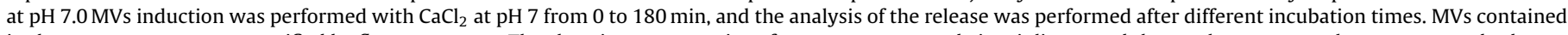

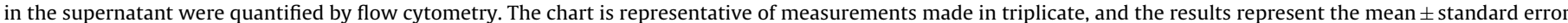

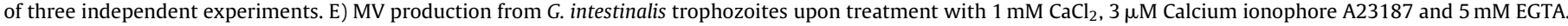

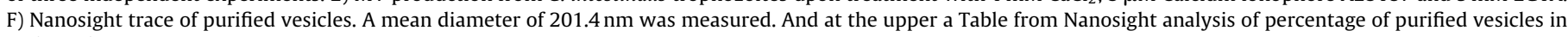
various size ranges.

The bar graph represents the mean \pm standard error of three independent experiments.

forms with $\mathrm{M} \beta \mathrm{CD}$ (methyl- $\beta$-cyclodextrin) at different concentrations, and we saw a dose-dependent inhibition of MV formation from 25 to $60 \%$ with increasing $\mathrm{M} \beta C D(2.5 \mu \mathrm{M}-10 \mu \mathrm{M})$, showing that the depletion of membrane cholesterol decreases EMV formation (Fig. 2A).

The inhibition of MV formation by removal of cholesterol suggests that trophozoites of $G$. intestinalis may diminish the parasite's ability to attach to host cell We next performed the adhesion assay using trophozoites either non-treated or treated with $2.5-10 \mu \mathrm{M}$ of $\mathrm{M} \beta C D$, and we detected a dose-dependent inhibition of the attachment of G. intestinalis to host cells (Fig. 2B).

The importance of lipid raft structure and MV release in the attachment to the host cell was notably verified when $G$. intestinalis treated with $5 \mu \mathrm{M}$ of M $\beta C D$ was used in an adhesion assay for $3 \mathrm{~h}$ in the presence of MVs. We saw that the parasites treated with $5 \mu \mathrm{M} M \beta C D$ were unable to attach to Caco-2 cells, and the addition of MVs restored the ability to attach in a dose-dependent manner
(Fig. 2C). These results suggest that MVs bring back certain physical properties to the membrane of the trophozoites, and probably increase the presence of a putative molecule-receptor ligation.

\subsection{Trophozoites from Giardia intestinalis secrete MVs that aid parasite attachment to host cells}

To investigate whether MVs from G. intestinalis could facilitate the adhesion of trophozoites to host cells, we performed an adhesion assay using monolayers of Caco- 2 cells, that resemble the enterocytes lining the small intestine, and trophozoites of $G$. intestinalis WB strain. Monolayers of Caco-2 cells in the semiconfluent state were incubated with $1 \times 10^{6}$ trophozoites of $G$. intestinalis in the presence of different concentrations of MVs from G. intestinalis, for 1 and $3 \mathrm{~h}$ at $37{ }^{\circ} \mathrm{C}$ and $5 \% \mathrm{CO}_{2}$. Cells were then washed, stained with Giemsa and quantified by light microscopy. We detected a slight dose-dependent increase of G. intestinalis 

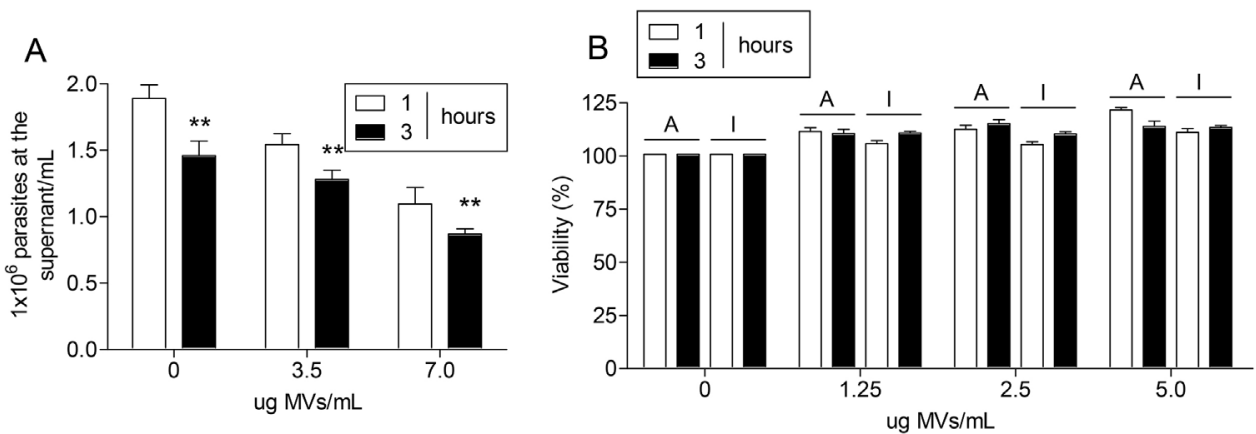

Fig. 2. Effect of lipid raft disruption by cholesterol depletion on MV production.

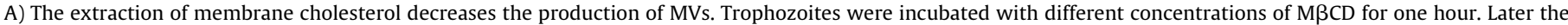

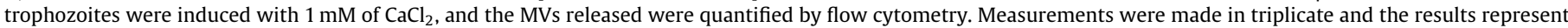

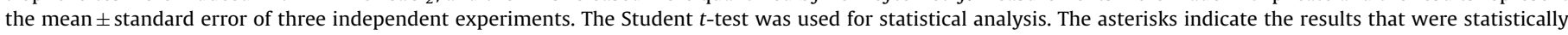

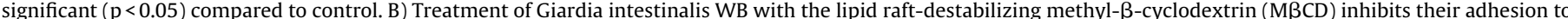

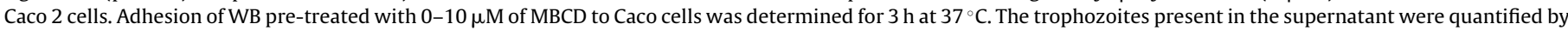

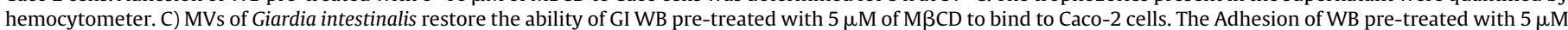

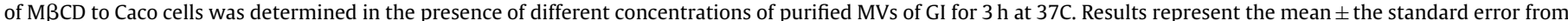

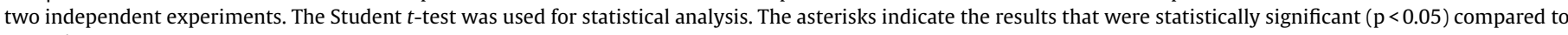
control.

A
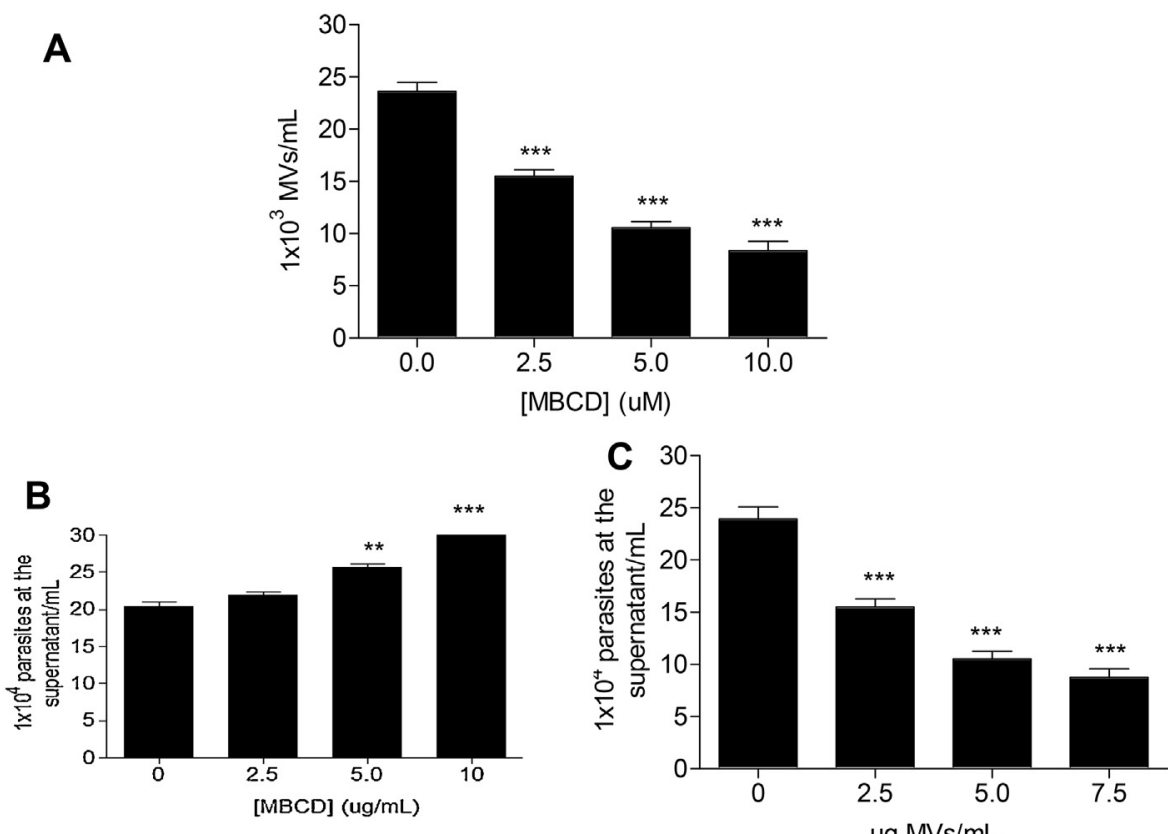

Fig. 3. Effect of Giardia intestinalis microvesicles on parasite adherence to Caco-2 cells.

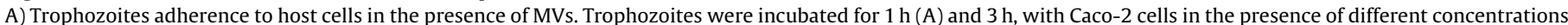

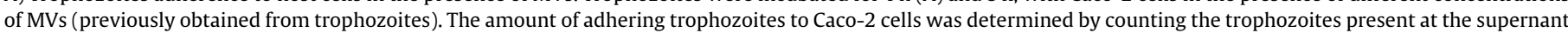

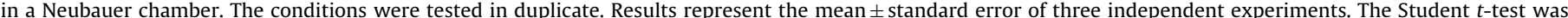

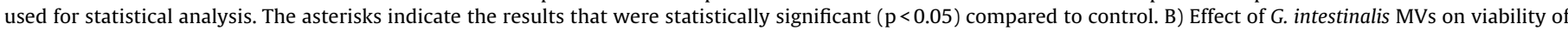

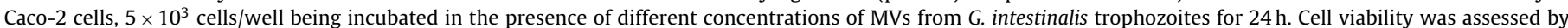

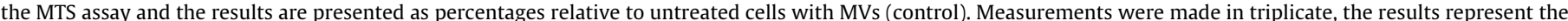

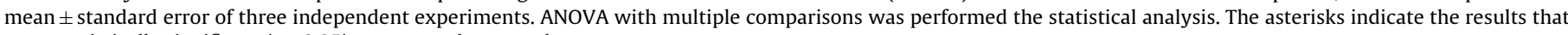
were statistically significant $(\mathrm{p}<0.05)$ respect to the control.

attachment to Caco-2 cells at $1 \mathrm{~h}$, and a strong 3-fold increase of adhesion of $G$. intestinalis to intestinal cells when parasites and host cells were incubated with $7 \mu \mathrm{g}$ of MVs compared to that without MVs. (Fig. 3A). Microvesicles treated with proteinase $\mathrm{K}$ $\left(0.05 \mathrm{mg} / \mathrm{ml}\right.$; Sigma Aldrich) for $1 \mathrm{~h}$ at $37^{\circ} \mathrm{C}$ and heat inactivated for incubation at $95^{\circ} \mathrm{C}$ for $10 \mathrm{~min}$ were used as adhesion assays controls. The treated-MVs had no effect on the attachment of trophozoites to Caco cells (not shown)

To analyze the specificity of this MV-mediated effect, we next used MVs of $G$. Intestinalis in an invasion assay, using metacyclic trypomastigotes forms of $T$. cruzi and Vero cells. Even using higher concentration of MVs $(10 \mu \mathrm{g})$, the rate of metacyclic trypomastigotes invasion was not modified in the presence of $G$. intestinalis MVs that the Mvs could have a specific effect on the parasite and not on Vero Cells. (data not shown).

\subsection{MVs communicate with neighbouring cells and face innate immunity}

Having shown the importance of MVs for cell adhesion, we next investigated the impact of MVs on neighbouring cells and in stimulating innate immunity. For this purpose, we analysed the effect 
A
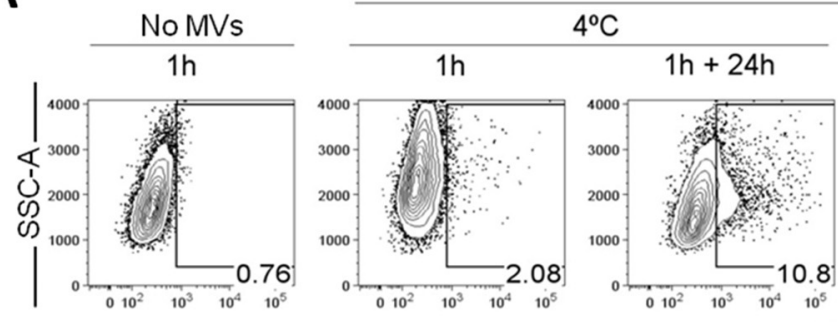

+ PKH-67-labeled MVs
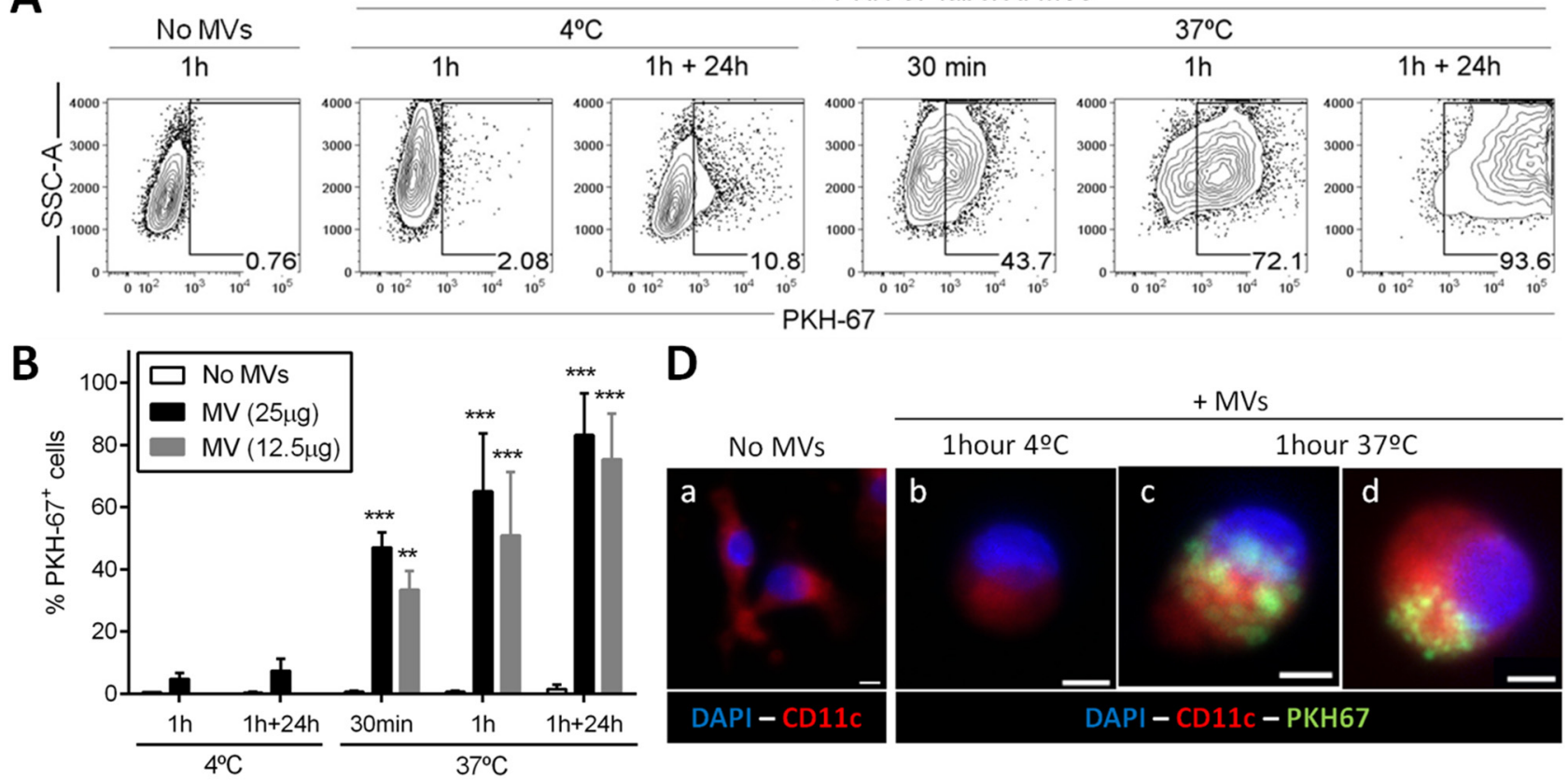

D

$\mathrm{PKH}-67$
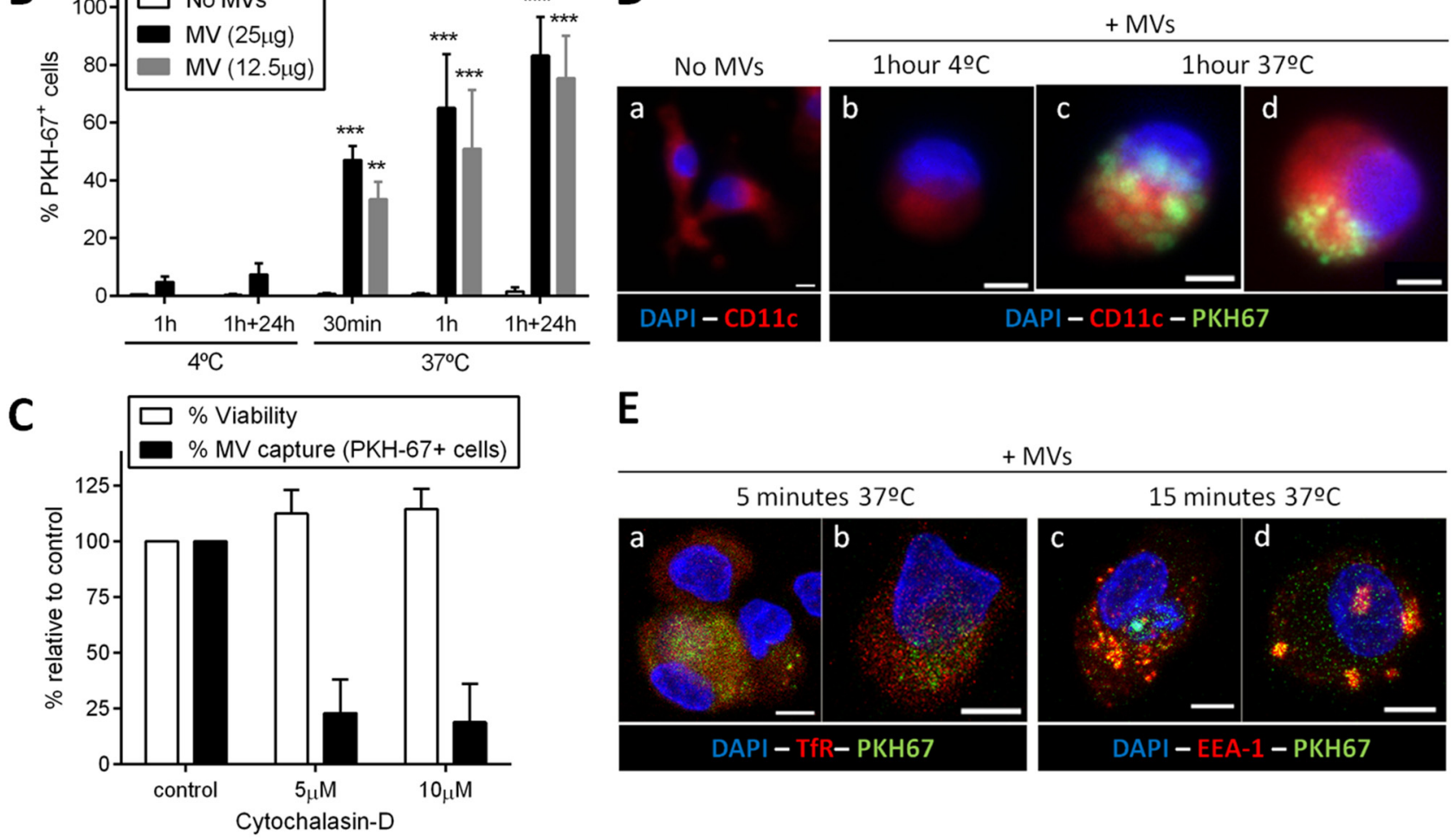

\section{E}

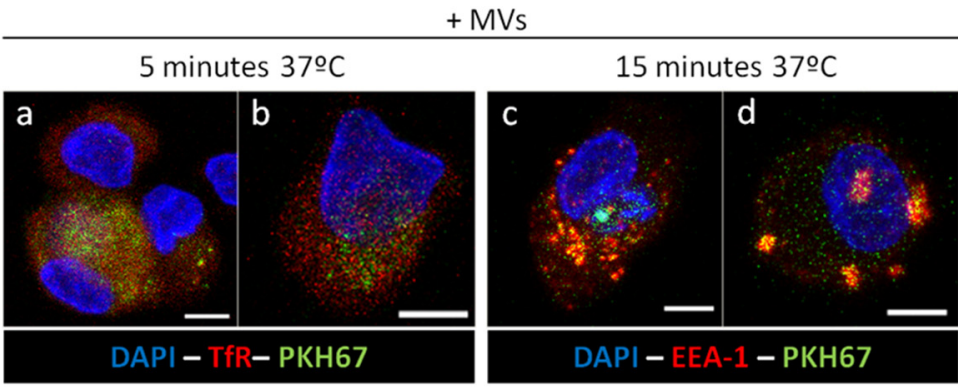

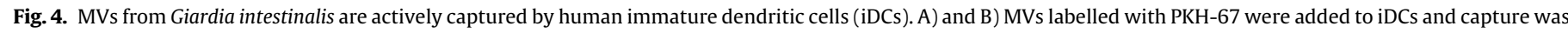

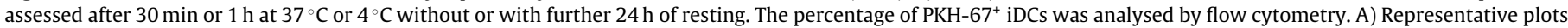

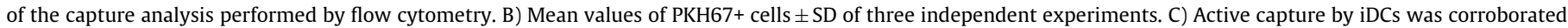

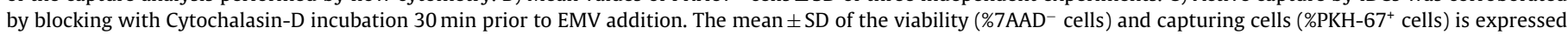

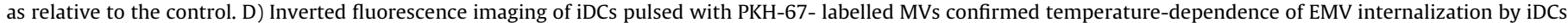

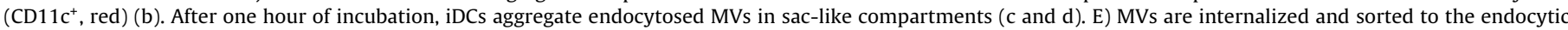

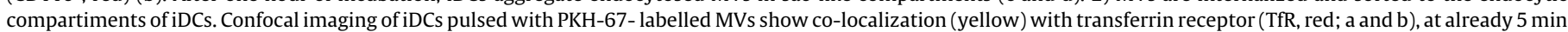

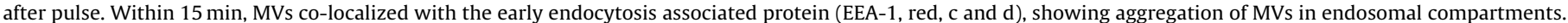
(For interpretation of the references to color in this figure legend, the reader is referred to the web version of this article.)

of MVs on the viability of Caco-2 cells and the ability of MVs to be captured by and modulate DC function.

Firstly, Caco- 2 cells were incubated in the presence of different concentrations of MVs derived from G. intestinalis for 24 and $48 \mathrm{~h}$, and a MTS viability assay was performed. After three independent experiments, we did not detect any effect on the viability of Caco-2 cells using different concentrations of MVs (Fig. 3B). We then analysed the interaction between MVs and DCs. Vesicles from GI were labelled with the aliphatic fluorophore PKH-67, and the interaction between MVs and iDCs was assessed by capture, phenotype of capturing cells, and alloproliferation analysis (Fig. 4).

Time-course experiments revealed that $G$. intestinalis MVs are rapidly internalized by iDCs (30-40\% positively labelled cells only 30 min after pulse). Of note, capture of MVs did not affect viability of iDCs (Fig. 4A, B). Noticeably, capture was inhibited almost completely at low temperature $\left(4^{\circ} \mathrm{C}\right)$ and by the addition of cytochalasin D to the iDC culture, thus indicating a clear endocytic component on the capture of MVs (Fig. 4B and C). MV internalization was confirmed also by inverted fluorescent microscopy, and cells pulsed at $4{ }^{\circ} \mathrm{C}$ showed no MVs within them (Fig. 4D). To further confirm the involvement of the endocytic pathway in the MV capture by iDCs, confocal images were taken at short time intervals. Five minutes after incubation, captured MVs colocalized with the early endocytosis marker Transferrin Receptor (TfR) (Fig. 4E). At later time points ( $15 \mathrm{~min}$ of incubation), MVs colocalized with the Early Endosome Associated protein (EEA-1, Fig. 4E), and after one hour of incubation, cells showed sac-like compartments where captured MVs probably aggregated all together (Fig. 4D).

To assess the capacity of MVs to induce DC maturation, iDCs were pulsed for one hour with MVs, washed, and further cultured for $24 \mathrm{~h}$. At this time point, classical activation markers such as CD83 and HLA-DR did not vary their expression. However, GI-MVs-capturing iDCs upregulated the activation marker CD25 (Fig. 5A) suggesting a mild activation of iDCs. This mild activation 

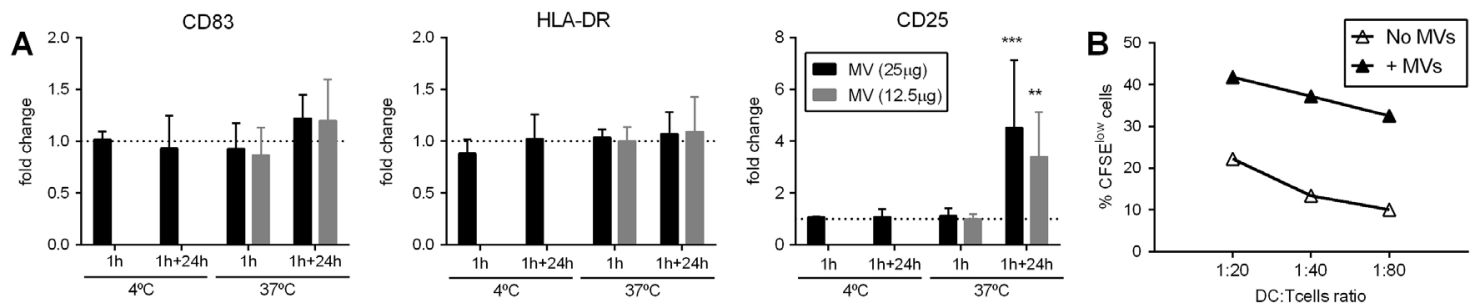

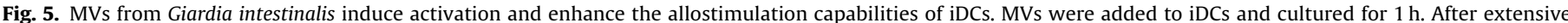

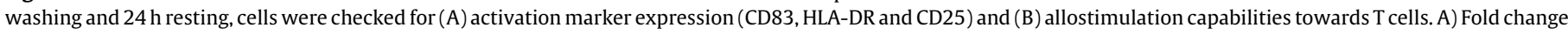

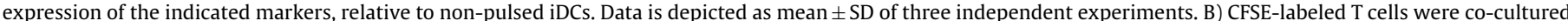

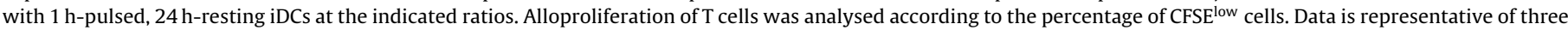
independent experiments.

was further confirmed by the increase of alloantigenic stimulation potential of DCs in T cell alloproliferation experiments (Fig. 5B).

\subsection{Proteomic analysis of MVs suggest a modulation effect to host cells}

We investigated the content of MVs released by mid-log trophozoites and by trophozoites induced to Cyst form by proteomic assays. The mass spectrometry analysis showed differences in the content of these MVs (Table 1). Only 11 proteins were identified from the trophozoite stage, seven of them previously reported as present in MVs in other organisms as described in the vesiclepedia (Kalra et al., 2012; http://microvesicles.org). In the case of MVs from cyst transition, 80 proteins were detected (36 of them still unknown), and from the 44 remaining, 24 proteins corresponded to previously identified EVs proteins (Table 1). Interestingly, in the cyst stage, proteins involved in pathogenesis like VSPs and giardins were identified in MVs (Table 1). Further investigation is needed to identify specific markers released by the different MV populations.

\section{Discussion}

\subsection{Trofozoites from Giardia intestinalis respond to} environmental changes releasing MVs that facilitate the interaction with host cells

The results presented in this study have demonstrated that trophozoites from Giardia intestinalis are able to release MVs in response to different $\mathrm{pH}$ levels, and calcium (Fig. 1). Many reports have shown the secretion of MVs during an interaction of protozoans with host cells. One interesting example of the role of MVs affecting the environment is the murine malaria model infected with Plasmodium berghei, which develops cerebral malaria (CM). EVs isolated from plasma derived from infected erythrocytes resulted in a potent activation of macrophages via toll-like receptors, whereas plasma-derived MVs from naïve animals did not induce macrophages (Couper et al., 2010). In the same murine model, the abrogation of MVs formation in mice knocked out for the gene $A B C A 1$ protected these animals against $\mathrm{CM}$, demonstrating a link between EV production and pathogenesis (Combes et al., 2005).

In Trypanosoma cruzi, Cestari et al. (2012), demonstrated that metacyclic trypomastigotes forms when in contact with the monocytic THP-1 cell line, release MVs that inhibit C3 convertase, and aid the parasite to invade host cells. Recently, other groups have shown that MVs from $T$. cruzi have different sizes, and different effects. Bayer-Santos et al. (2013), found two types of EVs secreted by the parasites. Later, Garcia-Silva et al. (2014), Linhares-Lacerda et al. (2015), and Fernandez-Calero et al.(2015) showed the involvement of miRNA in MV transfer to host cells, indicating this mechanism as a novel modulating effect against neighbouring cells.
Other reports have also described that the protozoan Trichomonas vaginalis secretes extracellular vesicles similar to mammalian exosomes. The parasite-derived exosomes contain RNA, conserved exosomal proteins and parasite-specific proteins (Twu et al., 2013). They also demonstrated that T. vaginalis exosomes are able to deliver their contents to host cells and modulate host cell immune responses. Interestingly, exosomes from highly adherent parasite strains increased the adherence of poorly adherent parasites to vaginal and prostate epithelial cells. In contrast, exosomes from poorly adherent strains had no measurable effect on parasite adherence (Twu et al., 2013).

\subsection{Microvesicle release is associated with lipid rafts and MVs are derived from the plasma membrane}

The mechanism of MV release has been associated with induction or stimulation of cells producing an increase in intracellular calcium, which is mobilized by calpain in turn inhibiting flippase and activating scramblease. The biophysical step including the exovagination of the phospholipid bilayer is a mechanism still poorly understood. Different reports have shown that cholesterol should influence the lipid raft microdomains on the membrane that participate in MV formation. An interesting report by Del Conde et al. (2005), demonstrated that the coagulation process is dependent of the transference of tissue factors released from monocyte-MVs to platelets. This release is dependent of lipid raft microdomains. Moreover, the shedding of MVs containing tissuefactor was abolished with the depletion of membrane cholesterol. Interestingly the giardia genome (Giardia DB) has no annotation to GPI-anchor proteins, a family of proteins associated to sphingolipids and cholesterol on the plasma membrane and related to lipid raft formation. However a putative transamidase annotated could be transferring GPI to other acceptors. The recently described genome in G. intestinalis (Morrison et al., 2007) revealed the presence of lipids synthesis and metabolic genes. Which proteins and structures are related to lipids rafts formation need to be validated. Recently De Chatterjee et al. (2015) hypothesized that Lipid rafts act as molecular sensors on the plasma membrane. They used conjugated cholera toxin B (CTXB) which binds GMI glycolipid demonstrating lipid rafts at the membrane, ventral disc and caudal flagella. Moreover nystatin and filipin III, two well known LR disrupting agents inhibited the CTXB binding indicating that lipid rafts contain cholesterol and the removal destabilized the microdomains. De Chatterjee et al. (2015) discussed the possible connection between lipids rafts and sphingolipids metabolism in Giardia regulating the encystation process.

Our findings support the involvement of cholesterol in MV release, as we observed an inhibition of MV production using different concentrations of $\mathrm{M} \beta C D$ (Fig. 2A). Furthermore, the absence of cholesterol inhibited the parasites attachment to the host cell, and 
Table 1

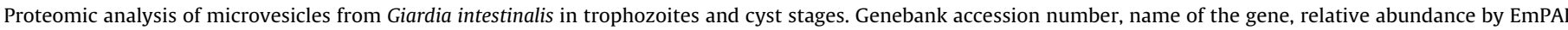
data, and presence in homologues dataset of MVs (microvesicles.org) are shown.

\begin{tabular}{|c|c|c|c|}
\hline Accession & Name & $\begin{array}{l}\text { Total } \\
\text { EmPAI }\end{array}$ & $\begin{array}{l}\text { Homologues } \\
\text { Evs }\end{array}$ \\
\hline 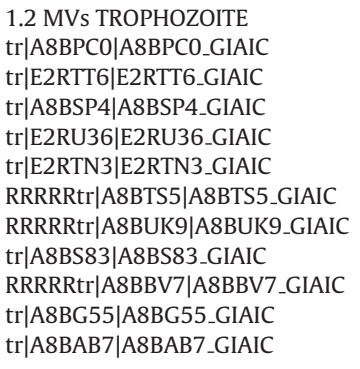 & $\begin{array}{l}\text { Alpha-tubulin } \\
\text { Ornithine carbamoyltransferase } \\
\text { Glyceraldehyde-3-phosphate dehydrogenase } \\
\text { Arginine deiminase } \\
\text { Glucosamine-6-phosphate isomerase } \\
\text { Splicing factor-like protein, putative } \\
\text { Dynein heavy chain, putative } \\
\text { rRNA biogenesis protein RRP5 } \\
\text { Uncharacterized protein } \\
\text { Uncharacterized protein } \\
\text { Uncharacterized protein }\end{array}$ & $\begin{array}{l}2.79 \\
2.42 \\
2 \\
2 \\
2 \\
1.04 \\
0.75 \\
0.14 \\
0.08 \\
0.06 \\
0.05\end{array}$ & $\begin{array}{l}\text { yes } \\
\text { yes } \\
\text { yes } \\
\text { yes } \\
\text { yes } \\
\text { no } \\
\text { yes } \\
\text { yes } \\
\text { ND } \\
\text { ND } \\
\text { ND }\end{array}$ \\
\hline 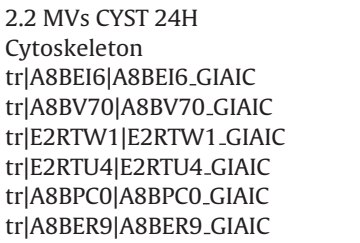 & $\begin{array}{l}\text { Beta tubulin } \\
\text { Actin related protein } \\
\text { Alpha- } 7.2 \text { giardin } \\
\text { Alpha- } 11 \text { giardin } \\
\text { Alpha-tubulin } \\
\text { Median body protein }\end{array}$ & $\begin{array}{l}4.86 \\
2.13 \\
1.44 \\
0.43 \\
0.11 \\
0.06\end{array}$ & $\begin{array}{l}\text { yes } \\
\text { yes } \\
\text { no } \\
\text { no } \\
\text { yes } \\
\text { no }\end{array}$ \\
\hline $\begin{array}{l}\text { Membrane and transport } \\
\text { tr|A8BN35|A8BN35_GIAIC } \\
\text { RRRRRtr|A8BT70|A8BT70_GIAIC } \\
\text { RRRRRtr|A8B7D3|A8B7D3_GIAIC } \\
\text { tr|E2RU51|E2RU51_GIAIC } \\
\text { RRRRRtr|A8BGS8|A8BGS8_GIAIC } \\
\text { tr|A8BUL9|A8BUL9_GIAIC } \\
\text { tr|A8BKH9|A8BKH9_GIAIC }\end{array}$ & $\begin{array}{l}\text { Kinesin-like protein } \\
\text { Ciliary dynein heavy chain } 11 \\
\text { Dynein heavy chain } \\
\text { TMP52 } \\
\text { WD-repeat membrane protein } \\
\text { Cation-transporting ATPase 2, putative } \\
\text { Phospholipid-transporting ATPase IA, putative }\end{array}$ & $\begin{array}{l}0.14 \\
0.11 \\
0.11 \\
0.15 \\
0.11 \\
0.06 \\
0.06\end{array}$ & $\begin{array}{l}\text { yes } \\
\text { yes } \\
\text { yes } \\
\text { no } \\
\text { no } \\
\text { yes } \\
\text { yes }\end{array}$ \\
\hline $\begin{array}{l}\text { Metabolic enzymes } \\
\text { tr|E2RTT6|E2RTT6_GIAIC } \\
\text { RRRRRtr|A8BQI1|A8BQI1_GIAIC } \\
\text { RRRRRtr|A8B3P9|A8B3P9_GIAIC } \\
\text { RRRRRtr|A8B3D3|A8B3D3_GIAIC } \\
\text { RRRRRtr|A8BKZ7|A8BKZ7_GIAIC } \\
\text { tr|A8BYC4|A8BYC4_GIAIC } \\
\text { tr|A8BVT2|A8BVT2_GIAIC } \\
\text { tr|A8BW47|A8BW47_GIAIC } \\
\text { RRRRRtr|A8B8T1|A8B8T1_GIAIC }\end{array}$ & $\begin{array}{l}\text { Ornithine carbamoyltransferase } \\
\text { Phosphatidylinositol transfer protein alpha isoform } \\
\text { Acyl-CoA synthetase } \\
\text { Inorganic polyphosphate/ATP-NAD kinase, putative } \\
\text { Protein tyrosine phosphatase-like protein } \\
\text { Peroxiredoxin } 1 \\
\text { Midasin ATPase nuclear } \\
\text { Kinase, NEK } \\
\text { CDC19 Pyruvate kinase }\end{array}$ & $\begin{array}{l}1.78 \\
0.21 \\
0.02 \\
0.08 \\
0.08 \\
0.28 \\
0.12 \\
0.1 \\
0.08\end{array}$ & $\begin{array}{l}\text { yes } \\
\text { yes } \\
\text { yes } \\
\text { no } \\
\text { yes } \\
\text { yes } \\
\text { yes } \\
\text { no } \\
\text { yes }\end{array}$ \\
\hline $\begin{array}{l}\text { Nuclear proteins } \\
\text { tr|A8BUJ9|A8BUJ9_GIAIC } \\
\text { RRRRRtr|A8BYH2|A8BYH2_GIAIC } \\
\text { RRRRRtr|A8BTS5|A8BTS5_GIAIC } \\
\text { RRRRRtr|E2RU53|E2RU53_GIAIC } \\
\text { tr|A8B9T6|A8B9T6_GIAIC } \\
\text { RRRRRtr|E2RU87|E2RU87_GIAIC } \\
\text { tr|A8BN96|A8BN96_GIAIC }\end{array}$ & $\begin{array}{l}\text { Histone H4 } \\
\text { Histone H3 } \\
\text { Splicing factor-like protein, putative } \\
\text { Mre11 endonuclease } \\
\text { Nuclear LIM interactor-interacting factor } 1 \\
\text { Mlh2-like protein } \\
\text { Reverse transcriptase/endonuclease, putative }\end{array}$ & $\begin{array}{l}0.85 \\
0.06 \\
0.23 \\
0.16 \\
0.11 \\
0.09 \\
0.06\end{array}$ & $\begin{array}{l}\text { yes } \\
\text { yes } \\
\text { no } \\
\text { yes } \\
\text { no } \\
\text { no } \\
\text { yes }\end{array}$ \\
\hline 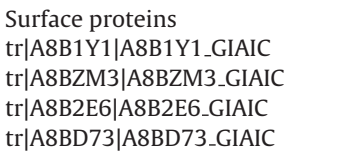 & $\begin{array}{l}\text { VSP } \\
\text { VSP with INR } \\
\text { VSP } \\
\text { VSP }\end{array}$ & $\begin{array}{l}0.8 \\
0.39 \\
0.3 \\
0.24\end{array}$ & $\begin{array}{l}\text { no } \\
\text { no } \\
\text { no } \\
\text { no }\end{array}$ \\
\hline 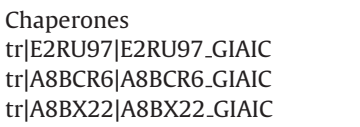 & $\begin{array}{l}14-3-3 \text { protein } \\
\text { Cytosolic HSP70 } \\
\text { Stress-induced-phosphoprotein } 1\end{array}$ & $\begin{array}{l}0.56 \\
0.53 \\
0.07\end{array}$ & $\begin{array}{l}\text { yes } \\
\text { yes } \\
\text { yes }\end{array}$ \\
\hline $\begin{array}{l}\text { Other } \\
\text { RRRRRtr|A8BK23|A8BK23_GIAIC } \\
\text { tr|A8B5R5|A8B5R5_GIAIC } \\
\text { RRRRRtr|A8B463|A8B463_GIAIC } \\
\text { tr|A8BAF5|A8BAF5_GIAIC } \\
\text { RRRRRtr|A8BYJ|A8BYJ8_GIAIC } \\
\text { tr|A8B4Q1|A8B4Q1_GIAIC } \\
\text { tr|A8B4S4|A8B4S4_GIAIC } \\
\text { tr|A8BNT5|A8BNT5_GIAIC } \\
\text { RRRRRtr|A8BUV6|A8BUV6_GIAIC }\end{array}$ & $\begin{array}{l}\text { Coiled-coil protein } \\
\text { Protein } 21.1 \\
\text { Protein } 21.1 \\
\text { Coiled-coil protein } \\
\text { Mucin-like protein } \\
\text { NOD3 protein, putative } \\
\text { Retinoic acid induced } 17 \text {-like protein } \\
\text { Ribosomal protein L9 } \\
\text { Zinc finger domain protein }\end{array}$ & $\begin{array}{l}0.17 \\
0.23 \\
0.14 \\
0.08 \\
0.14 \\
0.1 \\
0.11 \\
0.12 \\
0.08\end{array}$ & $\begin{array}{l}\text { no } \\
\text { no } \\
\text { no } \\
\text { no } \\
\text { yes } \\
\text { no } \\
\text { no } \\
\text { yes } \\
\text { no }\end{array}$ \\
\hline
\end{tabular}


Table 1 (Continued)

\begin{tabular}{|c|c|c|c|}
\hline Accession & Name & $\begin{array}{l}\text { Total } \\
\text { EmPAI }\end{array}$ & $\begin{array}{l}\text { Homologues } \\
\text { Evs }\end{array}$ \\
\hline \multicolumn{4}{|l|}{ Unknown } \\
\hline RRRRRtr|A8BC17|A8BC17_GIAIC & Uncharacterized protein & 0.32 & \\
\hline RRRRRtr|A8B9Q6|A8B9Q6_GIAIC & Uncharacterized protein & 0.22 & \\
\hline tr|A8BHN6|A8BHN6_GIAIC & Uncharacterized protein & 0.21 & \\
\hline $\operatorname{tr|A8BQ51|A8BQ51\_ GIAIC~}$ & Uncharacterized protein & 0.21 & \\
\hline $\operatorname{tr} \mid$ A8B4W6|A8B4W6_GIAIC & Uncharacterized protein & 0.2 & \\
\hline tr|A8BB64|A8BB64_GIAIC & Uncharacterized protein & 0.19 & \\
\hline 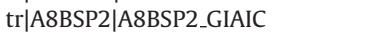 & Uncharacterized protein & 0.18 & \\
\hline tr|D3KGH8|D3KGH8_GIAIC & Uncharacterized protein & 0.15 & \\
\hline RRRRRtr|A8B639|A8B639_GIAIC & Uncharacterized protein & 0.15 & \\
\hline tr|A8BFN9|A8BFN9_GIAIC & Uncharacterized protein & 0.13 & \\
\hline 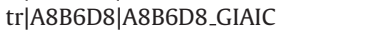 & Uncharacterized protein & 0.12 & \\
\hline tr|D3KI60|D3KI60_GIAIC & Uncharacterized protein & 0.11 & \\
\hline $\operatorname{tr} \mid$ A8BMW0|A8BMW0_GIAIC & Uncharacterized protein & 0.1 & \\
\hline RRRRRtr|A8BRV4|A8BRV4_GIAIC & Uncharacterized protein & 0.1 & \\
\hline RRRRRtr|A8BZ05|A8BZ05_GIAIC & Uncharacterized protein & 0.1 & \\
\hline tr|A8BAB7|A8BAB7_GIAIC & Uncharacterized protein & 0.1 & \\
\hline tr|A8B688|A8B688_GIAIC & Uncharacterized protein & 0.1 & \\
\hline 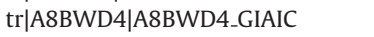 & Uncharacterized protein & 0.1 & \\
\hline tr|D3KHS6|D3KHS6_GIAIC & Uncharacterized protein & 0.09 & \\
\hline 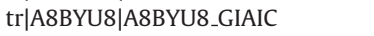 & Uncharacterized protein & 0.09 & \\
\hline RRRRRtr|D3KGZ8|D3KGZ8_GIAIC & Uncharacterized protein & 0.09 & \\
\hline $\operatorname{tr} \mid$ A8BGCO|A8BGC0_GIAIC & Uncharacterized protein & 0.09 & \\
\hline RRRRRtr|A8BU47|A8BU47_GIAIC & Uncharacterized protein & 0.08 & \\
\hline tr|D3KG74|D3KG74_GIAIC & Uncharacterized protein & 0.08 & \\
\hline 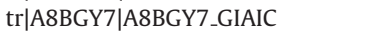 & Uncharacterized protein & 0.07 & \\
\hline RRRRRtr|A8BDU0|A8BDU0_GIAIC & Uncharacterized protein & 0.07 & \\
\hline 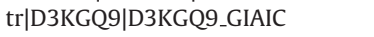 & Uncharacterized protein & 0.07 & \\
\hline tr|D3KG99|D3KG99_GIAIC & Uncharacterized protein & 0.07 & \\
\hline $\operatorname{tr} \mid$ A8BQP6|A8BQP6_GIAIC & Uncharacterized protein & 0.06 & \\
\hline $\operatorname{tr} \mid$ A8BXY2|A8BXY2_GIAIC & Uncharacterized protein & 0.06 & \\
\hline RRRRRtr|A8BN55|A8BN55_GIAIC & Uncharacterized protein & 0.06 & \\
\hline tr|A8BK19|A8BK19_GIAIC & Uncharacterized protein & 0.06 & \\
\hline RRRRRtr|A8B4 × 8|A8B4 $\times 8$ _GIAIC & Uncharacterized protein & 0.06 & \\
\hline tr|A8BAT6|A8BAT6_GIAIC & Uncharacterized protein & 0.06 & \\
\hline RRRRRtr|A8BC94|A8BC94_GIAIC & Uncharacterized protein & 0.05 & \\
\hline
\end{tabular}

it was subsequently restored by the exogenous presence of MVs (Fig. 2B).

\subsection{Microvesicles from Giardia intestinalis modulate dendritic} cells implicating them in the pathogenesis

Factors associated with the pathology of giardiasis indicate a likely mechanical alteration of intestinal mucosa for the attachment of the trophozoites, due to the involvement of cystein protease activities secreted by the parasite in contact with host cells. In fact, a lower activation or damage to host cell should be associated with a low inflammation that progresses in giardiasis. Previous work using mouse models to determine the role of various cytokines in immunity to Giardia have shown that IL-6 plays a critical role in the control of primary infections with this parasite (Bienz et al., 2003; Zhou et al., 2003). Here, we have analysed whether MVs release by trophozoites should alter dendritic cells, which are a family of professional antigen-presenting cells (APCs), that reside in all peripheral tissues in an immature state, capable of antigen uptake and processing. Dendritic cells (DC) when activated are key to enhanced cytokine secretion and enable DC migration and recruitment of other cell types. DC capture of Giardia MVs suggests an effective contact with host cells. Furthermore, in vitro or in vivo assays could indicate the role of MVs in dendritic cell modulation. Recently, some manuscripts have shown and reviewed the role of dendritic cells during protozoan -host cell interaction (i.e. Boscardin et al., 2016; Weidner et al., 2016; Feijó et al., 2016; Ersching et al., 2016). However, there are no current reports involving MVs from parasites in modulating dendritic cell functions.

\subsection{Exosome and microvesicles content can alter neighbouring cells}

There are numerous examples in the literature of protozoa releasing large amounts of material into the extracellular space as a form of cellular communication with host cells (Garcia-Silva et al., 2014; Linhares-Lacerda et al., 2015; Fernandez-Calero et al., 2015; Cestari et al., 2012). In Giardia intestinalis, the diarrhoea and malabsorption could be a direct result of the interaction of the parasite with the intestinal epithelium which might be mediated by the parasite itself, or by substances it secretes or by MVs that could alter neighbouring cells. Analysis of Caco-2 human intestinal epithelial cells demonstrated that Giardia infection resulted in a strong alteration of the expression profile of these cells, including stress-response genes and chemokines, as seen by microarray analyses (Roxström-Lindquist et al., 2005). Transcriptional changes in G. intestinalis during interaction with intestinal epithelial cells were also monitored by microarray analysis of $G$. intestinalis cDNAs, and indicated up-regulation of genes encoding enolase, cysteine proteinase, arginine deiminase and oxygen defence proteins (Ringqvist et al., 2011). Interestingly, contact of G. intestinalis with epithelial cells resulted in the release of metabolic enzymes (arginine deaminase, ornithine carbamoyltransferase and enolase) from $G$. intestinalis, which disabled host immune factors including nitric oxide (Ringqvist et al., 2008). A previous study also demonstrated that the excretory-secretory products (ESP) of G. lamblia contained major antigen(s) responsible for protection against infection in mice (Kaur et al., 1999, 2001). Oral administration of G. lamblia ESPs into BALB/c mice stimulated a Th2 response, which led to intestinal histological changes characterized by eosinophilic infiltration, and can induce host cell apoptosis, hypercellularity, and 


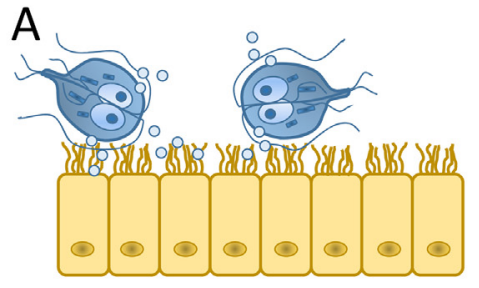

B

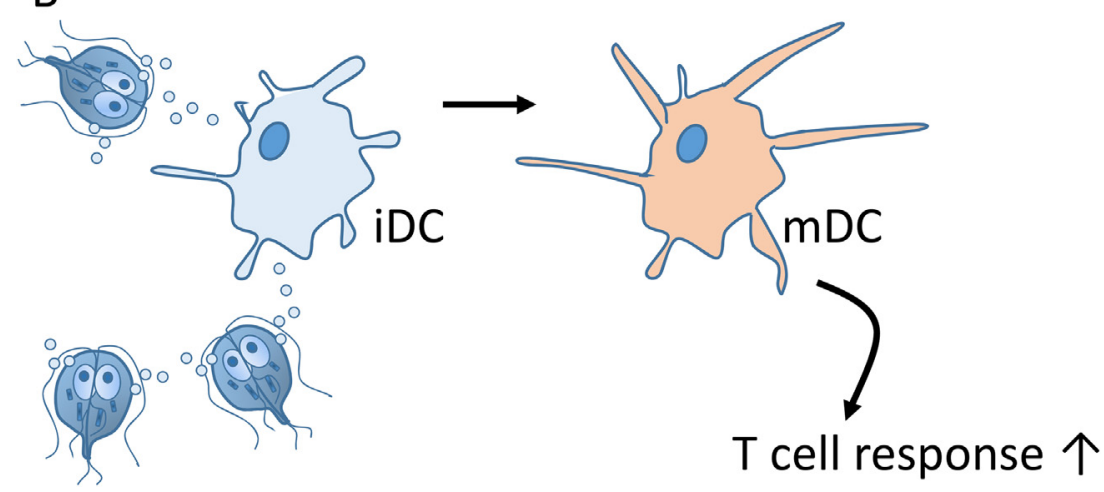

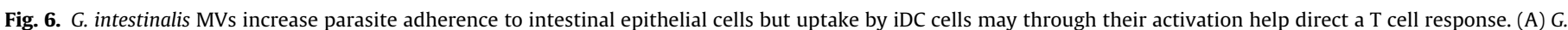

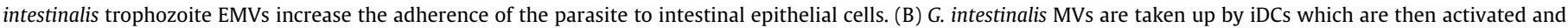
mature (showing upregulation of CD25). T cell alloproliferation experiments then showed an increase of the alloantigenic stimulation potentail of DCs.

enterocytic desquamation (Jiménez et al., 2004). Glycoproteins in G. lamblia ESP were found to induce antibody production during giardiasis (Jiménez et al., 2007). Cysteine proteases present in G. lamblia ESP were essential for the induction of antibody and cytokine production in BALB/c mice infected with ESP (Jiménez et al., 2009). Our findings of small RNAs in the cargo of EMVs suggest that the parasite could transfer material to host cells trough EMVs, modifying the cell phenotype. An interesting previous report supports this possibility; the infection of human ileocecal adenocarcinoma cell line HCT-8 with Giardia intestinalis can induce host cell apoptosis. Signs of chromatin condensation and caspase 3 activation was found to occur in monolayers exposed to different $G$. intestinalis assemblages (Koh et al., 2013). Nuclear fragmentation and cell death was suppressed with a caspase 3 inhibitor. The most important point was the demonstration that cellular extracts from Giardia intestinalis were able to induce apoptosis without contact with the parasite. This fact supports the idea that EVs should alter the host cell. MicroRNAs have been shown to have a role in cancer, cell reprogramming, hypertension regulation and other chronic diseases (reviewed by Tao et al., 2016; Stepicheva and Song, 2016; Makarova et al., 2016), and could be essential in host-parasite cell interactions.

Taken together, our findings and new concepts reveal another facet to the ever increasingly complex environment of dynamic cellular communication between parasites and hosts. The content of MVs, including protein and nucleic acids, may modify the cell phenotype avoiding innate immunity and producing the infection (Fig. 6). The identification of cellular targets and inhibitors of microvesiculation could potentially represents a novel strategy to control the diseases, and are currently under investigation.

\section{Acknowledgements}

We would like to thank Dr. F.B. to facilitate Senior researcher stay of M.R at the Germans trias e pujol Institute, Badalona, Spain. We also thank to Luz Valero from S.C.S.I.E. Universidad de Valencia for proteomic analysis to Dr. G, Valdameri for helping with the edition of the figures and Dr. Wanderson Da Rocha for sharing his laboratory at the Universidad Federal de Parana. Finally, this study has received support from FIOCRUZ, CNPq, and Programa Basico de Parasitologia AUXPE 2041/2011 (CAPES), Brazil. M.R is currently fellow from CNPq-Brazil and I.E.O, Was fellow from CAPES.

\section{Appendix A. Supplementary data}

Supplementary data associated with this article can be found, in the online version, at http://dx.doi.org/10.1016/j.ejcb.2017.01.005.

\section{References}

Adam, R.D., 2001. Biology of Giardia lamblia. Clin. Microbiol. Rev. 14, 447-475. Aurelian, S.M., Cheţa, D.M., Onicescu, D., 2014. Microvesicles-potential biomarkers for the interrelations atherosclerosis/type 2 diabetes mellitus. Rom. J. Morphol. Embryol. 55 (3 Suppl), 1035-1039.

Barteneva, N.S., Maltsev, N., Vorobjev, I.A., 2013. Microvesicles and intercellular communication in the context of parasitism. Front. Cell. Infect. Microbiol. 3.

Bayer-Santos, E., Aguilar-Bonavides, C., Rodrigues, S.P., Cordero, E.M., Marques, A.F., Varela-Ramirez, A., Choi, H., Yoshida, N., da Silveira, J.F., Almeida, I.C., 2013. Proteomic analysis of Trypanosoma cruzi secretome: characterization of two populations of extracellular vesicles and soluble proteins. J. Proteome Res. $12,883-897$.

Benchimol, M.D.S., De Souza, W., 2011. The ultrastructure of giardia during growth and differentiation. In: Hugo, D., Luján, S.S. (Eds.), Giardia: A Model Organism. Springer, Vienna.

Bienz, M., Dai, W.J., Welle, M., Gottstein, B., Müller, N., 2003. Interleukin-6-deficient mice are highly susceptible to Giardia lamblia infection but exhibit normal intestinal immunoglobulin A responses against the parasite. Infect. Immun. 71, 1569-1573.

Boscardin, S.B., Rosa, D.S., Kamphorst, A.O., Trumpfheller, C., 2016. Dendritic cells in tolerance and immunity against pathogens. J. Immunol. Res. 2016, 1-2.

Cestari, I., Ansa-Addo, E., Deolindo, P., Inal, J.M., Ramirez, M.I., 2012. Trypanosoma cruzi immune evasion mediated by host cell-derived microvesicles. J. Immunol. 188, 1942-1952.

Combes, V., Coltel, N., Alibert, M., van Eck, M., Raymond, C., Juhan-Vague, I., Grau, G.E., Chimini, G., 2005. ABCA1 gene deletion protects against cerebral malaria: potential pathogenic role of microparticles in neuropathology. Am. J. Pathol. 166, 295-302.

Couper, K.N., Barnes, T., Hafalla, J.C.R., Combes, V., Ryffel, B., Secher, T., Grau, G.E., Riley, E.M., de Souza, J.B., 2010. Parasite-derived plasma microparticles contribute significantly to malaria infection-induced inflammation through potent macrophage stimulation. PLoS Pathog. 6, e1000744.

De Chatterjee, A., Mendez, T.L., Roychowdhury, S., Das, S., 2015. The assembly of GM1 glycolipid- and cholesterol-enriched raft-like membrane microdomains is important for giardial encystation. Infect. Immun. 83 (5), 2030-2042. 
Del Conde, I., Shrimpton, C.N., Thiagarajan, P., López, J.A., 2005. Tissue-factor-bearing microvesicles arise from lipid rafts and fuse with activated platelets to initiate coagulation. Blood 106, 1604-1611.

Deolindo, P., Evans-Osses, I., Ramirez, M.I., 2013. Microvesicles and exosomes as vehicles between protozoan and host cell communication. Biochem. Soc. Trans. 41 (1), 252-257.

Embley, T.M., Hirt, R.P., 1998. Early branching eukaryotes? Curr. Opin. Genet. Dev. 8 (December (6)), 624-629.

Ersching, J., Basso, A.S., Kalich, V.L., Bortoluci, K.R., Rodrigues, M.M., 2016. A human trypanosome suppresses CD8+ T cell priming by dendritic cells through the induction of immune regulatory CD4+ Foxp3+ T cells. PLoS Pathog. 12 (6)

Evans-Osses, I., Reichembach, L.H., Ramirez, M.I., 2015. Exosomes or microvesicles? Two kinds of extracellular vesicles with different routes to modify protozoan-host cell interaction. Parasitol. Res. 114, 3567-3575.

Faso, C., Hehl, A.B., 2011. Membrane trafficking and organelle biogenesis in Giardia lamblia: use it or lose it. Int. J. Parasitol. 41, 471-480

Feijó, D., Tibúrcio, R., Ampuero, M., Brodskyn, C., Tavares, N., 2016. Dendritic cells and leishmania infection: adding layers of complexity to a complex disease. J. Immunol. Res.

Fernandez-Calero, T., Garcia-Silva, R., Pena, A., Robello, C., Persson, H., Rovira, C., Naya, H., Cayota, A., 2015. Profiling of small RNA cargo of extracellular vesicles shed by Trypanosoma cruzi reveals a specific extracellular signature. Mol. Biochem. Parasitol. 199, 19-28.

Garcia-Silva, M.R., Cabrera-Cabrera, F., das Neves, R.F.C., Souto-Padrón, T., de Souza, W., Cayota, A., 2014. Gene expression changes induced by Trypanosoma cruzi shed microvesicles in mammalian host cells: relevance of tRNA-derived halves. BioMed Res. Int. 2014, 305239.

Hanevik, K., Hausken, T., Morken, M.H., Strand, E.A., Mørch, K., Coll, P., Helgeland, L., Langeland, N., 2007. Persisting symptoms and duodenal inflammation related to Giardia duodenalis infection. J. Infect. 55, 524-530.

House, S.A., Richter, D.J., Pham, J.K., Dawson, S.C., 2011. Giardia flagellar motility is not directly required to maintain attachment to surfaces. PLoS Pathog. 7 , e1002167.

Jiménez, J.C., Fontaine, J., Grzych, J.-M., Dei-Cas, E., Capron, M., 2004. Systemic and mucosal responses to oral administration of excretory and secretory antigens from Giardia intestinalis. Clin. Diagn. Lab. Immunol. 11, 152-160.

Jiménez, J.C., Morelle, W., Michalsky, J.-C., Dei-Cas, E., 2007. Excreted/secreted glycoproteins of G. intestinalis play an essential role in the antibody response. Parasitol. Res. 100, 715-720.

Jiménez, J.C., Fontaine, J., Creusy, C., Fleurisse, L., Grzych, J.-M., Capron, M., Dei-Cas, E., 2014. Antibody and cytokine responses to Giardia excretory/secretory proteins in Giardia intestinalis-infected BALB/c mice. Parasitol. Res. 113, 2709-2718.

Julich, H., Willms, A., Lukacs-Kornek, V., Kornek, M., 2014. Extracellular vesicle profiling and their use as potential disease specific biomarker. Front. Immunol.

Kalra, H., Simpson, R.J., Ji, H., Aikawa, E., Altevogt, P., Askenase, P., Bond, V.C., Borràs, F.E., Breakefield, X., Budnik, V., Buzas, E., Camussi, G., Clayton, A., Cocucci, E., Falcon-Perez, J.M., Gabrielsson, S., Gho, Y.S., Gupta, D., Harsha, H.C., Hendrix, A., Hill, A.F., Inal, J.M., Jenster, G., Krämer-Albers, E.M., Lim, S.K., Llorente, A., Lötvall, J., Marcilla, A., Mincheva-Nilsson, L., Nazarenko, I., Nieuwland, R., Nolte-'t Hoen, E.N., Pandey, A., Patel, T., Piper, M.G., Pluchino, S., Prasad, T.S Rajendran, L., Raposo, G., Record, M., Reid, G.E., Sánchez-Madrid, F., Schiffelers, R.M., Siljander, P., Stensballe, A., Stoorvogel, W., Taylor, D., Thery, C., Valadi, H., van Balkom, B.W., Vázquez, J., Vidal, M., Wauben, M.H., Yáñez-Mó, M., Zoeller, M., Mathivanan, S., 2012. Vesiclepedia: a compendium for extracellular vesicles with continuous community annotation. PLoS Biol. 10 (12)

Kaur, H., Samra, H., Ghosh, S., Vinayak, V.K., Ganguly, N.K., 1999. Immune effector responses to an excretory-secretory product of Giardia lamblia. FEMS Immunol. Med. Microbiol. 23, 93-105.

Kaur, H., Ghosh, S., Samra, H., Vinayak, V.K., Ganguly, N.K., 2001. Identification and characterization of an excretory-secretory product from Giardia lamblia. Parasitology 123, 347-356.

Koh, W.H., Geurden, T., Paget, T., O’Handley, R., Steuart, R.F., Thompson, R.C., Buret, A.G., 2013. Giardia duodenalis assemblage-specific induction of apoptosis and tight junction disruption in human intestinal epithelial cells: effects of mixed infections. J. Parasitol. 99 (April (2)), 353-358, http://dx.doi.org/10.1645/GE3021.1 (Epub 2012 Aug 27).

Lauwaet, T., Davids, B.J., Torres-Escobar, A., Birkeland, S.R., Cipriano, M.J., Preheim, S.P., et al., 2007. Protein phosphatase 2A plays a crucial role in Giardia lamblia differentiation. Mol. Biochem. Parasitol. 152 (1), 80-89 (PubMed: 17204341).

Linhares-Lacerda, L., Palu, C.C., Ribeiro-Alves, M., Paredes, B.D., Morrot, A., Garcia-Silva, M.R., Cayota, A., Savino, W., 2015. Differential expression of
microRNAs in thymic epithelial cells from Trypanosoma cruzi acutely infected mice: putative role in thymic atrophy. Front. Immunol. 6.

Lower, X., Vino, A.C., Tedgui, A., Boulanger, C.M., 2014. Microvesicles as cell-cell messengers in cardiovascular diseases. Circ. Res. 114 (January (2)), 345-353, http://dx.doi.org/10.1161/CIRCRESAHA.113.300858.

Luján, H.D., Mowatt, M.R., Byrd, L.G., Nash, T.E., 1996. Cholesterol starvation induces differentiation of the intestinal parasite Giardia lamblia. Proc. Natl. Acad. Sci. U. S. A. 93 (July (15)), 7628-7633.

Marcilla, A., Martin-Jaular, L., Trelis, M., de Menezes-Neto, A., Osuna, A., Bernal, D., Fernandez-Becerra, C., Almeida, I.C., del Portillo, H.A., 2014. Extracellular vesicles in parasitic diseases. J. Extracell. Vesicles 3.

Makarova, J.A., Shkurnikov, M.U., Wicklein, D., Lange, T., Samatov, T.R., Turchinovich, A.A., 2016. Tonevitsky AG6Intracellular and extracellular microRNA: an update on localization and biological role. Prog. Histochem. Cytochem. 51 (3-4), 33-49.

McCaffery, J.M., Gillin, F.D., 1994. Giardia lamblia: ultrastructural basis of protein transport during growth and encystation. Exp. Parasitol. 79, 220-235.

Morrison, H.G., McArthur, A.G., Gillin, F.D., Aley, S.B., Adam, R.D., Olsen, G.J., Best, A.A., Cande, W.Z., Chen, F., Cipriano, M.J., Davids, B.J., Dawson, S.C., Elmendorf, H.G., Hehl, A.B., Holder, M.E., Huse, S.M., Kim, U.U., Lasek-Nesselquist, E., Manning, G., Nigam, A., Nixon, J.E., Palm, D., Passamaneck, N.E., Prabhu, A., Reich, C.I., Reiner, D.S., Samuelson, J., Svard, S.G., Sogin, M.L., 2007. Genomic minimalism in the early diverging intestinal parasite Giardia lamblia. Science 317 (September (5846)), 1921-1926.

Oberhuber, G., Stolte, M., 1997. Symptoms in patients with giardiasis undergoing upper gastrointestinal endoscopy. Endoscopy 29, 716-720.

Ratajczak, J., Wysoczynski, M., Hayek, F., Janowska-Wieczorek, A., Ratajczak, M.Z., 2006. Membrane-derived microvesicles: important and underappreciated mediators of cell-to-cell communication. Leukemia 20 (9), 1487-1495

Reiner, D.S., McCaffery, M., Gillin, F.D., 1990. Sorting of cyst wall proteins to a regulated secretory pathway during differentiation of the primitive eukaryote Giardia lamblia. Eur. J. Cell Biol. 53 (1), 142-153.

Ringqvist, E., Palm, J.E.D., Skarin, H., Hehl, A.B., Weiland, M., Davids, B.J., Reiner, D.S., Griffiths, W.J., Eckmann, L., Gillin, F.D., et al., 2008. Release of metabolic enzymes by Giardia in response to interaction with intestinal epithelial cells. Mol. Biochem. Parasitol. 159, 85-91.

Ringqvist, E., Avesson, L., Söderbom, F., Svärd, S.G., 2011. Transcriptional changes in Giardia during host-parasite interactions. Int. J. Parasitol. 41, 277-285.

Roxström-Lindquist, K., Ringqvist, E., Palm, D., Svärd, S.1, 2005. Giardia lamblia-induced changes in gene expression in differentiated Caco-2 human intestinal epithelial cells. Infect. Immun. 73, 8204-8208.

Shevchenko, A., Jensen, O.N., Podtelejnikov, A.V., Sagliocco, F., Wilm, M., Vorm, O., Mortensen, P., Shevchenko, A., Boucherie, H., Mann, M., 1996. Linking genome and proteome by mass spectrometry: large-scale identification of yeast proteins from two dimensional gels. Proc. Natl. Acad. Sci. U. S. A. 93, $14440-14445$.

Solaymani-Mohammadi, S., Singer, S.M., 2011. Host immunity and pathogen strain contribute to intestinal disaccharidase impairment following gut infection. J. Immunol. 187, 3769-3775.

Stepicheva, N.A., Song, J.L., 2016. Function and regulation of microRNA-31 in development and disease. Mol Reprod Dev. 83 (8), 654-674.

Tao, L., Bei, Y., Chen, P., Lei, Z., Fu, S., Zhang, H., Xu, J., Che, L., Chen, X., Sluijter, J.P., Das, S., Cretoiu, D., Xu, B., Zhong, J., Xiao, J., Li, X., 2016. Crucial role of miR-433 in regulating cardiac fibrosis. Theranostics 6 (12), 2068-2083.

Twu, O., de Miguel, N., Lustig, G., Stevens, G.C., Vashisht, A.A., Wohlschlegel, J.A., Johnson, P.J., 2013. Trichomonas vaginalis exosomes deliver cargo to host cells and mediate host: parasite interactions. PLoS Pathog. 9, e1003482.

Weidner, J.M., Kanatani, S., Uchtenhagen, H., Varas-Godoy, M., Schulte, T., Engelberg, K., Gubbels, M.J., Sun, H.S., Harrison, R.E., Achour, A., Barragan, A., 2016. Migratory activation of parasitized dendritic cells by the protozoan Toxoplasma gondii 14-3-3 protein. Cell.

Woessner, D.J., Dawson, S.C., 2012. The giardia median body protein is a ventral disc protein that is critical for maintaining a domed disc conformation during attachment. Eukaryot. Cell 11, 292-301.

Woodhead, V.E., Stonehouse, T.J., Binks, M.H., Speidel, K., Fox, D.A., Gaya, A., Hardie, D., Henniker, A.J., Horejsi, V., Sagawa, K., Skubitz, K.M., Taskov, H., Todd 3rd, R.F., van Agthoven, A., Katz, D.R., Chain, B.M., 2000. Novel molecular mechanisms of dendritic cell-induced T cell activation. Int. Immunol. 12 (July (7)), 1051-1061.

Zhou, P., Li, E., Zhu, N., Robertson, J., Nash, T., Singer, S.M., 2003. Role of interleukin-6 in the control of acute and chronic Giardia lamblia infections in mice. Infect. Immun. 71, 1566-156. 